\title{
Magnesium calcite in Muschelkalk limestones of the Polish part of the Germanic Basin
}

\author{
Katarzyna J. Stanienda-Pilecki ${ }^{1}$
}

Accepted: 16 February 2018 / Published online: 5 March 2018

(c) The Author(s) 2018. This article is an open access publication

\begin{abstract}
Magnesium calcite, which is usually observed in many natural low-temperature environments, was identified in Triassic limestones of the Polish part of the Germanic Basin. The occurrence of unstable magnesium calcite in Triassic limestones is remarkable. High-Mg calcite was identified in all beds of the Muschelkalk Karchowice Formation: Lower Crinoidea Beds, Lower Biohermal Beds, Upper Crinoidea Beds and Upper Biohermal Beds. The general chemical formulas of magnesium calcite of mentioned unites are: $\left(\mathrm{Ca}_{0.87-0.80}, \mathrm{Mg}_{0.13-0.20}\right) \mathrm{CO}_{3},\left(\mathrm{Ca}_{0.83-0.75}, \mathrm{Mg}_{0.17-0.25}\right) \mathrm{CO}_{3},\left(\mathrm{Ca}_{0.81}, \mathrm{Mg}_{0.19}\right) \mathrm{CO}_{3}$, $\left(\mathrm{Ca}_{0.78-0.77}, \mathrm{Mg}_{0.22-0.23}\right) \mathrm{CO}_{3}$ respectively. This mineral originated probably during the early stage of diagenesis, during compaction of limestones deposited in a warm, shallow marine environment. Some amounts of magnesium come from high-Mg skeletons of marine organisms (such as echinoderms). Diagnenetic processes and the conditions in seawater, especially higher salinity, influence the preservation of high magnesium calcite in the Muschelkalk limestone of the Polish part of the Germanic Basin.
\end{abstract}

Keywords High-Mg calcite $\cdot$ Polish Muschelkalk sediments · Germanic Basin

\section{Introduction}

The area of the Polish part of the Germanic Basin is built of Muschelkalk limestones which include carbonate phases varying in magnesium content. Analyses of low-Mg calcite and high-Mg calcite show that these two carbonate phases differ, in stability, solubility and crystal structure. It is connected with different cationic size of $\mathrm{Ca}$ and $\mathrm{Mg}$, ionic radii length and the strength of ionic bonds. The strength of the ionic bond of two $\mathrm{Ca}$ ions is higher than the strength of the ionic bond between $\mathrm{Ca}$ and $\mathrm{Mg}$ ions. Therefore, the structure of a calcite crystal with $\mathrm{Mg}$ substitutions has weaker stability than the calcite without substitution. The solubility of high-Mg calcites is the same as that of low-Mg calcite and aragonite at temperatures below $42{ }^{\circ} \mathrm{C}$. Between 25 and $42{ }^{\circ} \mathrm{C}$, calcite with $15 \mathrm{~mol} \%$ of $\mathrm{MgCO}_{3}$ content is stable in relation to low magnesium calcite but unstable with respect to aragonite (Bertram et al. 1991). Calcite with $1.9 \mathrm{~mol} \%$

Katarzyna J. Stanienda-Pilecki

Katarzyna.Stanienda-Pilecki@polsl.pl

1 Department of Applied Geology, Faculty of Mining and Geology, Silesian University of Technology, ul. Akademicka 2, 44-100 Gliwice, Poland amount of $\mathrm{MgCO}_{3}$ is stable with respect to both low- $\mathrm{Mg}$ calcite and aragonite in temperatures from 25 to $64{ }^{\circ} \mathrm{C}$. At temperatures over $42{ }^{\circ} \mathrm{C}$, high-Mg calcite with the content of up to $15 \mathrm{~mol} \%$ of $\mathrm{MgCO}_{3}$ is stable in relation to low- $\mathrm{Mg}$ calcite at the temperature of $60{ }^{\circ} \mathrm{C}$ (Bertram et al. 1991). The amount of $\mathrm{MgCO}_{3}$ also influences the solubility of high magnesium calcite. According to the results of Morse et al. (2006), the solubility of high-Mg calcite is a function of $\mathrm{mol} \%$ of $\mathrm{MgCO}_{3}$ and it can exceed that of aragonite. The analysis of stability and solubility of this carbonate phase indicates that other factors than the $\mathrm{Mg}$ content can influence the solubility of high-Mg calcite, especially increased content of $\mathrm{CO}_{2}$ in ocean water (Morse et al. 2006). Low-Mg calcite and high-Mg calcite also have different crystal structure. Low-Mg calcite and high-Mg calcite have the same rhombohedral symmetry, but the unit cell parameters are different. According to Markgraf and Reeder (1985), low-Mg calcite standard cell parameters are as follows: $a_{0}=4.988 \AA$, $c_{0}=17.061 \AA$, $V=367.6(1) \AA^{3}$ and the ratio $c_{0} / a_{0}=3.42$. High magnesium calcite has different parameters: $a_{0}=4.941(2) \AA \hat{,} c_{0}=16.864(2) \AA \hat{,} V=356.60(22) \AA^{3}$ and the ratio $c_{0} / a_{0}=3.413$ (Althoff 1977). Because of that the peaks of low magnesium calcite and high magnesium calcite are different. According to Paquette and Reeder (1990), 
the amount of $\mathrm{MgCO}_{3}$ in biogenic high magnesium calcite fluctuates from 6.4 to $12.9 \mathrm{~mol} \%$-although the total amount of $\mathrm{MgCO}_{3}$ in high-Mg calcite could achieve $30 \mathrm{~mol} \%$. The results of their researches show that for $6.4 \mathrm{~mol} \%$ content of $\mathrm{MgCO}_{3}$ the parameters of high-Mg calcite cell present values: $a_{0}=4.9673(3) \AA \AA, c_{0}=16.9631(7) \AA \AA, V=362.48(4)$ $\AA^{3}$ and the ratio $c_{0} / a_{0}=3.415$. If the content of $\mathrm{MgCO}_{3}$ is $12.9 \mathrm{~mol} \%$, the parameters of high magnesium calcite crystal cell are: $a_{0}=4.9382(4) \AA \hat{,} c_{0}=16.832(1) \AA \hat{,}, V=355.48(7)$ $\AA^{3}$ and the ratio $c_{0} / a_{0}=3.4085$. According to Johnson (2002), $a_{0}$ and $c_{0}$ cell parameters of high-Mg calcite for $13.6 \% \mathrm{Mg}$ substitution (47.6 mol\% of $\mathrm{MgCO}_{3}$ ) are as following: $a_{0}=4.942 \AA$ and $c_{0}=16.85 \AA$.

Low magnesium calcite is usually presented by the chemical formula- $\left(\mathrm{Ca}_{0.998}, \mathrm{Mg}_{0.002}\right) \mathrm{CO}_{3}$ (Markgraf and Reeder 1985). According to Althoff (1977) high-Mg calcite is presented by the chemical formula $-\left(\mathrm{Ca}_{0.9}, \mathrm{Mg}_{0.1}\right) \mathrm{CO}_{3}$, but according to Morse and Mackenzie (1990) it is as follows$\left(\mathrm{Ca}_{0.85}, \mathrm{Mg}_{0.15}\right) \mathrm{CO}_{3}$. It is known that high magnesium calcite and aragonite represent unstable or metastable phases. They are transformed into low magnesium calcite in normal temperature $\left(26^{\circ} \mathrm{C}\right)$ and pressure (to $20 \mathrm{~atm}$.) (Deleuze and Brantley 1997; Fairchild et al. 2000; Zhang and Dave 2000). Moreover, aragonite and high-Mg calcite are often replaced by early diagenetic dolomite. It frequently occurs in ancient and modern environments where sulphate-evaporite deposits are strictly associated with dolomite deriving from early diagenetic processes.

To establish high-Mg calcite genesis and conditions of forming of this mineral, it is necessary to know the chemical conditions of the depositional paleoenvironment and the diagenetic processes which could generate and preserve this unstable carbonate phase, which is typical for modern sediments in Triassic deposits. The sources of magnesium are usually seawater and sometimes fresh waters. Magnesium could also come from weathered carbonate or silicate rocks. When delivered to seawater in a shelf zone, sometimes high-Mg calcite is formed (Mackenzie and Andersson 2013; Morse and Mackenzie 1990). High-Mg calcite is unstable with respect to low- $\mathrm{Mg}$ calcite as it may lose its $\mathrm{Mg}$ in time and alter to low-Mg calcite. If it is exposed to magnesium-rich pore waters, high magnesium calcite can gain additional Mg and be replaced by dolomite (Boggs 2010). Dolomite formation depends on $\mathrm{Mg} / \mathrm{Ca}$ ratio, temperature, $\mathrm{CO}_{2}$ content, reaction time and other factors (Mackenzie and Andersson 2013; Morse and Mackenzie 1990; Tucker and Wright 1990). High magnesium calcite, which includes up to $40 \%$ of $\mathrm{MgCO}_{3}$, (Zhang et al. 2010) is observed in many natural low-temperature environments (Böttcher et al. 1997; Fairbridge 1957). However, these high values are mostly referred to inorganic induced carbonates. Magnesium carbonates have also formed the skeletons of a wide variety of marine organisms (Stanley 2008). Namely the skeletons of crinoids, as well as of the entire phylum of Echinodermata, are composed of high-Mg calcite skeletons (Gorzelak et al. 2013, 2016). The ossicles are made up of porous calcite plates. However, placed inside the fossil they usually become closed by diagenetic calcite in optical continuity and each plate is a monocrystal with organic macromolecules in the crystal lattice.

High-Mg calcite is an unstable mineral. Substitution of $\mathrm{Mg}^{2+}$ into calcite lattice has significant influence on reactivity of carbonate solids because thermodynamic stability and dissolution/precipitation kinetics are changed (Böttcher et al. 1997). For that reason, high-Mg calcite turns into low magnesium calcite during diagenetic processes and high magnesium calcite is rare in ancient carbonates; however, it is possible to be found in sediments formed under high salinity conditions. In fresh water, low in $\mathrm{Mg}$, transformation of unstable minerals into stable ones does not proceed very quickly. It depends on the $\mathrm{Mg} / \mathrm{Ca}$ ratio, but particularly on the solid-liquid ratio (in other words: on the flow through behavior based on permeability and porosity). In water rich in magnesium, unstable phases of carbonate minerals, like high-Mg calcite, could be preserved. Sometimes neomorphic processes could influence the preservation of high magnesium calcite. In vadose zone less-stable aragonite and low$\mathrm{Mg}$ calcite are destroyed and stable high-Mg calcite is generated (Boggs 2010).

Occurrence of high magnesium calcite in the Muschelkalk limestone of the Polish part of the Germanic Basin (Opole) can indicate the special conditions of the marine water in the basin and sedimentary environment where these limestones were created (Stanienda 2006, 2011). Because the theory about the presence of the high-Mg calcite in the Muschelkalk limestone was doubtful, it was necessary to identify this mineral phase using different analytical methods.

The aim of this article is to assess the origin of high magnesium calcite (high-Mg calcite/magnesium calcite) in Muschelkalk limestones of the Polish part of the Germanic Basin with the aid of geochemical and mineralogical analyses.

\section{Geologic setting and sampling}

Triassic of Opole Silesia belongs to the Eastern part of the epicontinental Germanic Basin (Szulc 1990, 1993, 2000; Niedźwiedzki 2000; Feist-Burkhardt et al. 2008) (Fig. 1). The section of the Opole Silesia Triassic rocks includes Muschelkalk sediments. In this section, four stratigraphic units were distinguished: in the bottom Gogolin Beds, nextGórażdże Beds, Dziewkowice (Terebratula) Beds and Karchowice Beds (the top of section) (Figs. 2, 3). The samples for investigation were taken from the "Tarnów Opolski Deposit", which are situated in Silesia, in the area of Opole 


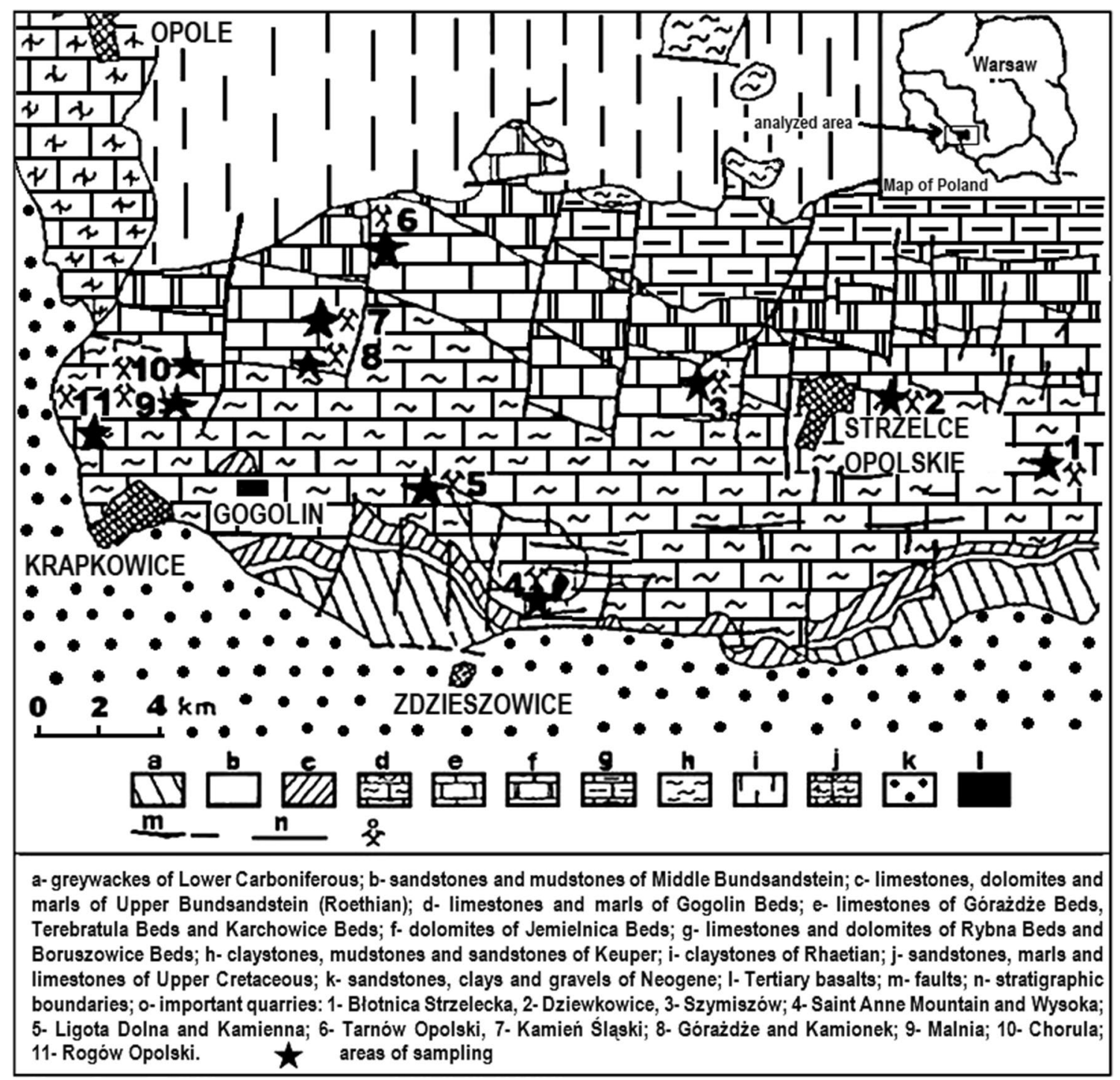

Fig. 1 Geological map of the central part of Opole Silesia (After Niedźwiedzki 2000; Stanienda 2013; modified)

(the south-western Poland) (Fig. 1). 82 samples were taken from "Tarnów Opolski Deposit": 2-from Terebratula Beds, 79-from Karchowice Beds and 1-from Diplopora Beds. 79 samples collected from the Karchowice Formation were analyzed (Fig. 3). The samples from this stratigraphic unit were chosen for study because of the highest content of $\mathrm{Mg}$ in the rocks. Four types of beds were distinguished in this formation: Lower Crinoidea Beds, Lower Biohermal Beds, Upper Crinoidea Beds and Upper Biohermal Beds (Figs. 2, 3). Lower Crinoidea Beds are composed of beige echinoderm-bearing limestones. Lower Biohermal Beds are built of large beige or grey sponge-crinoid-coral bioherms with inter-bioherm calcirudites. Upper Crinoidea Beds include very thick-bedded, beige, shell-echinoderm limestones, partially dolomitized with large-scale cross stratification, partially dolomitized and Upper Biohermal Beds are composed mainly of beige coral bioherms (Bodzioch 2005). Each type of beds was sampled.

\section{Identification of high-Mg calcite}

Methodology of the study

3 samples were taken from Lower Crinoidea Beds (3, 7 and 30), 24-from Lower Biohermal Beds (samples 1, 2, 6, 8, 9, $11,12,14,16,17,18,19,21,28,38,67,69,70,72,75,77$, 78, 80, 82), 21-from Upper Crinoidea Beds (samples 4, 5 , $10,13,15,20,22,24,25,26,27,56,61,65,68,71,73,74$, $76,79,81$ ) and 31 -from Upper Biohermal Beds (samples $23,28,31,34,35,36,37,39,40,41,42,43,44,45,46,47$, $48,49,50,51,52,53,54,55,57,59,60,62,63,64,66)$ (Fig. 3). Samples weighing 1-2 kg were taken. 
Fig. 2 Lithostratigraphic profile of Muschelkalk sediments of

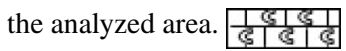
Diplopora Beds; คิคีค

Karchowice Beds (upper Biohermal limestones); 1 미맘 Karchowice Beds (upper Crinoidea limestones); Karchowice Beds (lower Biohermal limestones); $\frac{1000}{010}$ Karchowice Beds (lower Cri-

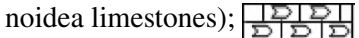
Dziewkowice (Terebratula)

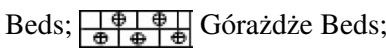
Gogolin Beds

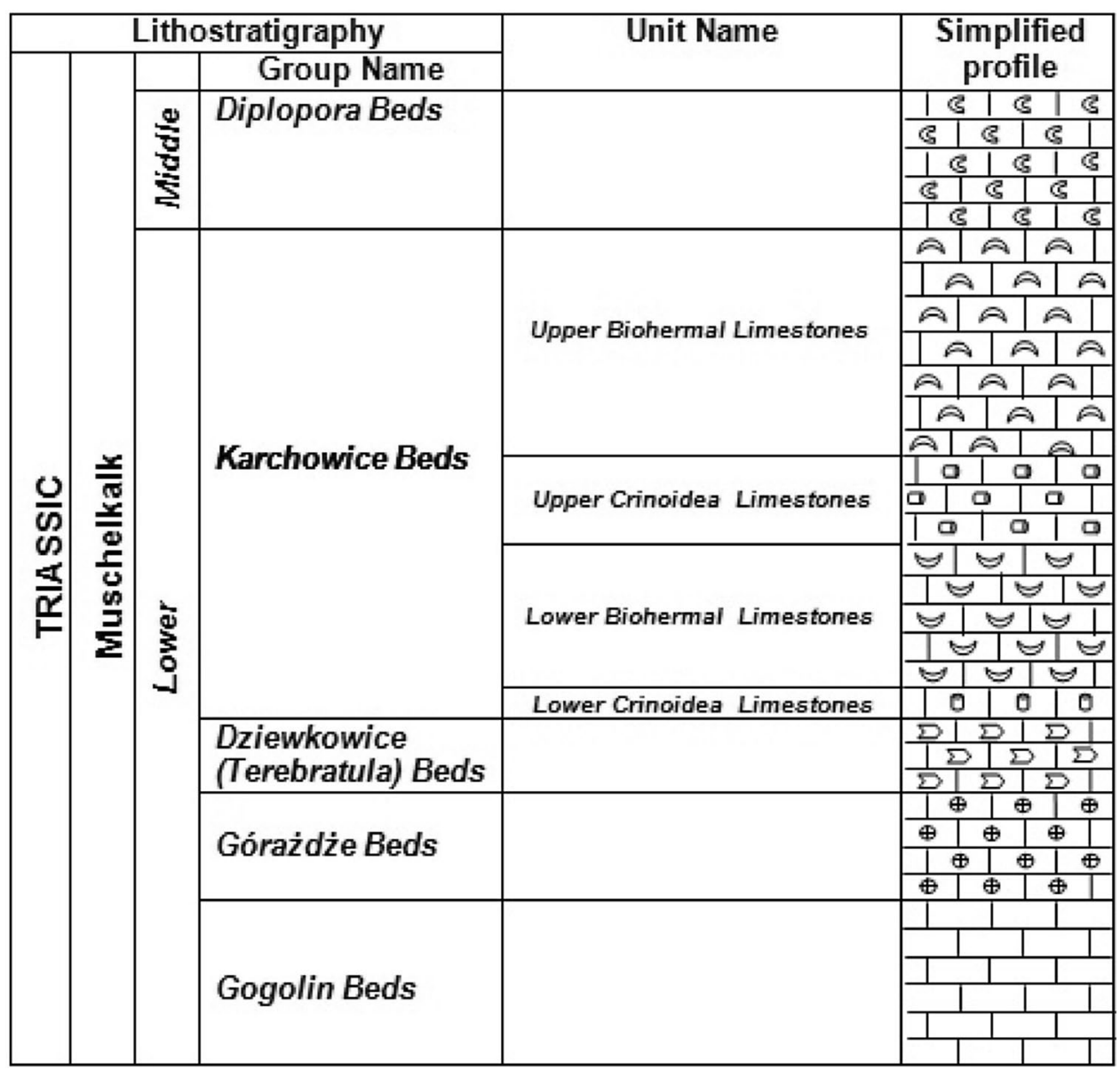

Measurements were carried out by means of microscopic analysis, FTIR, X-ray analyses, microprobe measurements including mapping based on microprobe measurements and ICP spectrometry.

The microscopic analysis was executed using an Axioskop Universal Microscope produced by Zeiss equipped with a photo camera. All samples were studied using the microscope. FTIR was done using Fourier Transform Spectrometer Bio-Rad FTS 135 which had $2 \mathrm{~cm}^{-1}$ resolution with a typical range of $400-4000 \mathrm{~cm}^{-1}$. Six samples were investigated by means of this method: two of lower Crinoidea limestones (samples 7 and 30), one of lower Biohermal limestones (sample 1), one of upper Crinoidea limestones (sample 22) and two samples of upper Biohermal limestones (samples 41 and 62) (Stanienda 2005). X-ray diffraction was carried out using an X-ray diffractometer XRD 7 made by Seifert-FPM. Measurements were executed with a range of $d$-spacing ( $($ ) from 0.8563 to $0.0953 \mathrm{~nm}$. Using this equipment it was possible to identify mineral phases but without an opportunity to determine the crystal structure. Four samples were investigated by means of this method: one of lower Crinoidea limestones (sample 7), two samples of upper Crinoidea limestones (samples 15 and 22) and one of upper Biohermal limestones (sample 62) (Stanienda 2006). Microprobe measurements were done using JEOLJCXA-733 microprobe equipped with a Link ISIS 300 spectrometer made by Oxford Instruments. The investigations were carried out on polished sections which were sputtered with a carbon coat. Four samples were investigated by this method: lower Crinoidea limestone (sample 7), lower Biohermal limestone (sample 1), upper Crinoidea limestone (sample 15) and upper Biohermal limestone (sample 41). The WDS method was applied to carry out quantitative analyses in micro areas with the selected points having different chemical composition. The content of the following chemical elements was determined: $\mathrm{O}, \mathrm{C}, \mathrm{Mg}, \mathrm{Si}, \mathrm{Ca}, \mathrm{Fe}$, and for some samples also $\mathrm{K}, \mathrm{Ba}, \mathrm{Sr}, \mathrm{Mn}, \mathrm{Al}, \mathrm{Na}, \mathrm{Cu}, \mathrm{Zn}, \mathrm{Pb}, \mathrm{Cd}$ and $\mathrm{Y}$. Mapping was executed using microprobe measurements method. The analysis was carried out applying the techniques of X-ray microanalysis EPMA, with the application of an X-ray microanalyzer JXA-8230 manufactured by JOEL. The analyses were carried out on polished sections which were sputtered with a carbon coat. Two samples were investigated with this method: lower Crinoidea limestone (sample 7) and upper Biohermal limestone (sample 41). The EDS analysis was carried out. The X-ray maps of one 


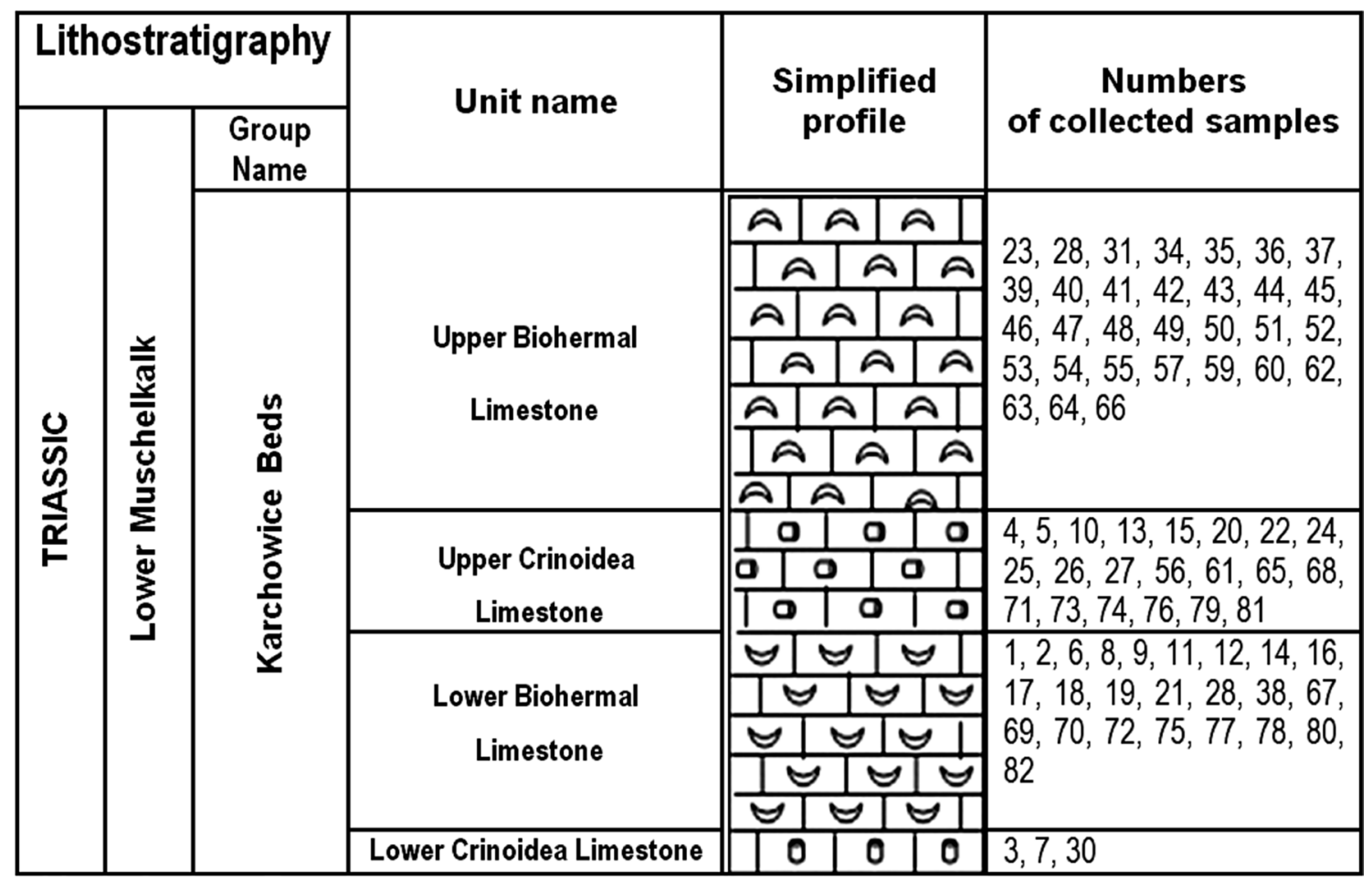

Fig. 3 Lithostratigraphic profile of the Karchowice Beds form the

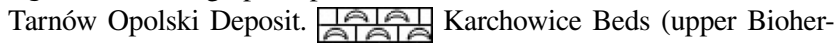

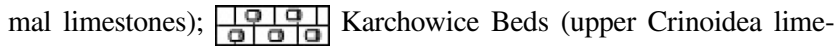

investigated microarea of sample 1 and two microareas of sample 5 were made using the EDS spectrometer. The content of the following elements was determined: $\mathrm{O}, \mathrm{C}, \mathrm{Mg}, \mathrm{Ca}$ and Fe. ICP spectrometry was carried out using an emission spectrometer ICP-AES of JY 2000 type with excitation in plasma induced conjugate. The measurement was based on atomic emission. Four samples were investigated by means of this method: lower Crinoidea limestone (sample 7), upper Crinoidea limestone (sample 22), lower Biohermal limestone (sample 1) and upper Biohermal limestone (sample 41). The content of the following elements was determined: $\mathrm{Ca}, \mathrm{Mg}, \mathrm{Fe}, \mathrm{Mn}, \mathrm{Sr}$ and $\mathrm{Ba}$.

\section{Results of the study}

\section{Microscopic analysis}

Results of the microscopic analysis (Fig. 4) allowed to distinguish only two carbonate phases: calcite and dolomite. The calcite phase includes low magnesium calcite and $\mathrm{Mg}$-calcite. Micritic grains of calcite usually form rock mass in limestones poor in allochems (Fig. 4A, B, E and F) and cement which forms bioclasts (Fig. 4C, D, G and $\mathrm{H}$ ) in limestones with allochems. Bigger, often sparry probably low magnesium calcite grains form veins or aggregates. They are usually different in shape and size stones); 밥일 Karchowice Beds (lower Biohermal limestones); 娄

(Fig. 4B, E). It is probably secondary calcite, a product of diagenetic processes, aggradation and recrystallization of primary micritic crystals. In some calcite crystals a rhombohedral cleavage is visible. Calcite crystals sometimes form palisade cement which surrounds allochems. Fragments of crinoids: columnals (Fig. 4D, H) or crown plates (Fig. 4C, G) usually dominate among bioclasts. Allochems are often filled with micrite. According to Dunham (1962) and Embry and Klovan (1971) classifications the analyzed limestones of Lower and Upper Crinoidea Beds represent crinoidal packstones. In Flügel's classification, the rocks represent standard microfacies of SMF 12 type (limestones with shell concentrations). Most echinoderm accumulations are composed of crinoids (SMF 12-CRIN) (Fig. 4D). According to Dunham (1962) and Embry and Klovan (1971) classifications limestones of Lower and Upper Biohermal Beds also represent packstones. In Flügel's classification the rocks represent standard microfacies type SMF 12 (limestones with shell concentrations). They belong to the SMF12-S group (coquina composed of shells without specific assignment) (Flügel 2004) (Fig. 4C, G and $\mathrm{H})$. Rocks of analyzed facies could be formed in various settings, including slopes, protected platforms, reefs and mounds and therefore also in the shallow epicontinental basin. This type of limestone can indicate in-place degradation or deposition subsequent to transport (Flügel 2004). 

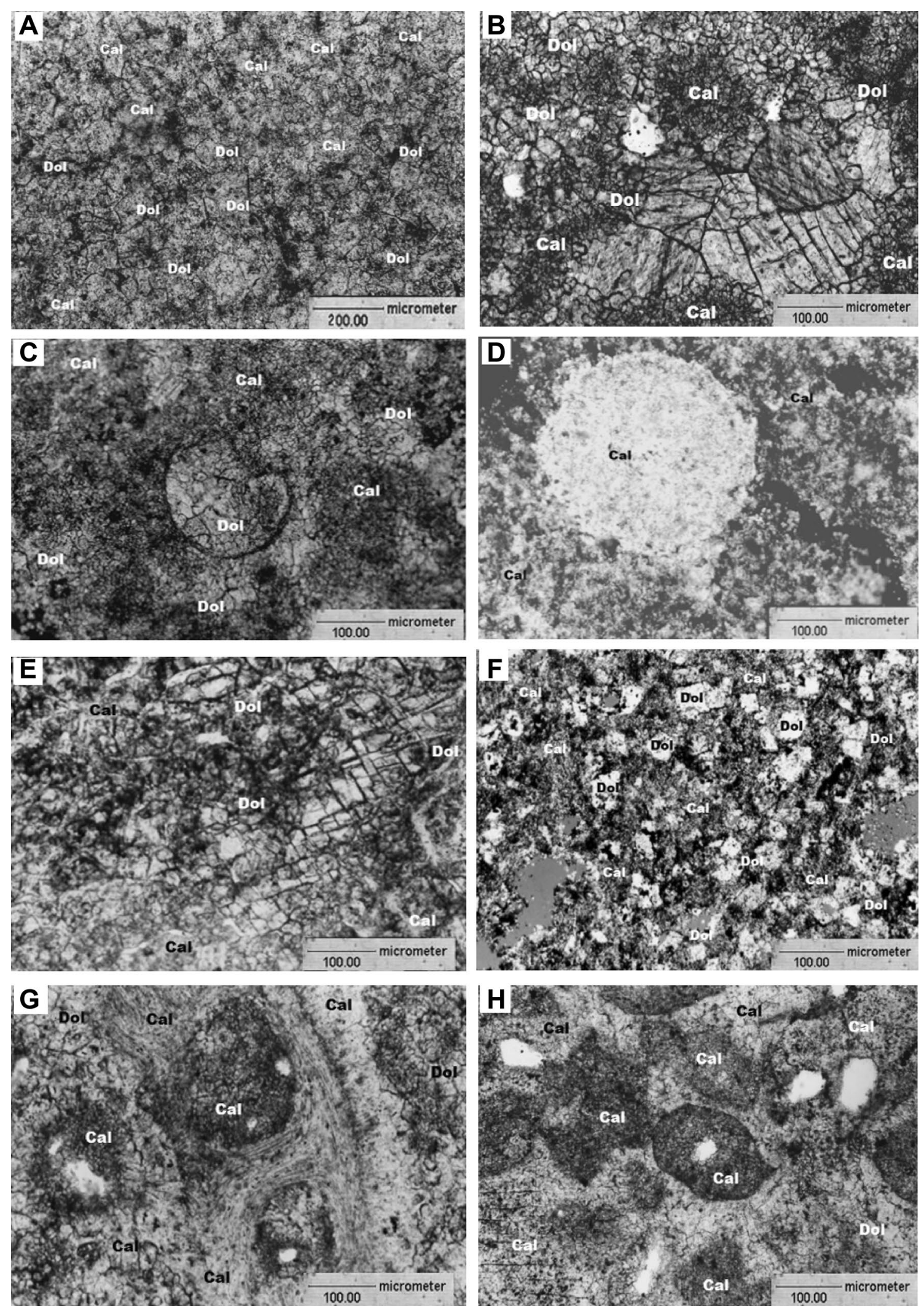
4Fig. 4 A Microscopic view of lower Crinoidea limestone (sample 7)-limestone built of sparry mass, built mainly of calcite crystals and rhombohedral dolomite crystals. 1N, Magn. $\times 200$ (Stanienda 2000, 2011). Cal, calcite phase; Dol, dolomite phase. B Microscopic view of lower Biohermal limestone (sample 2) -aggregates of coarse-grained calcite crystals and rhombohedral dolomite crystals in sparry rock mass. XN, Magn. $\times 100$ (Stanienda 2000, 2011). Cal, calcite phase; Dol, dolomite phase. C Microscopic view of lower Biohermal limestone (sample 8)—bioclast filled with coarse-grained calcite, in some places also dolomite in microsparry orthochem cement built mainly of calcite crystals and in some areas of rhombohedral dolomite crystals. XN, Magn. ×100 (Stanienda 2000, 2011). Cal, calcite phase; Dol, dolomite phase. D Microscopic view of upper Crinoidea limestone (sample 15) - in the foreground bioclast (crinoid circular stem plate) in microsparry orthochem cement built of calcite. XN, Magn. $\times 100$ (Stanienda 2000, 2011). Cal, calcite phase. E Microscopic view of upper Crinoidea limestone (sample 61) - on the right side vein filled with sparry calcite with visible rhombohedral cleavage. Apart from calcite crystals also rhombohedral dolomite crystals are visible in some places. XN, Magn. $\times 100$ (Stanienda 2000, 2011). Cal, calcite phase; Dol, dolomite phase. F Microscopic view of upper Biohermal limestone (sample 41) -rhombohedral dolomite crystals dominate here. In some areas micro-sparry and micritic calcite is visible. XN, Magn. $\times 100$ (Stanienda 2000, 2011). Cal, calcite phase; Dol, dolomite phase. G Microscopic view of upper Biohermal limestone (sample 57) —bioclast in sparry rock mass. In some places rhombohedral dolomite crystals are visible. XN, Magn. $\times 100$ (Stanienda 2000, 2011). Cal, calcite phase; Dol, dolomite phase. H Microscopic view of upper Biohermal limestone (sample 64) - group of bioclasts cemented by sparry, in some areas of rock, syntaxial calcite. In some places rhombohedral dolomite crystals are visible. XN, Magn. $\times 100$ (Stanienda 2000, 2011). Cal, calcite phase; Dol, dolomite phase

Microscopic analysis is also allowed to identify dolomite. All sparry rhombohedral crystals are the dolomite phase. These crystals are usually well visible in thin sections (Fig. 4A, B). In some samples it is possible to observe calcite pseudomorphs after dolomite (dedolomites). Some of them are filled with iron oxides.

The results of the microscopic study show that calcite phases dominate in most of the investigated limestone. The higher content of dolomite was observed in lower Crinoidea limestone and lower Biohermal limestone. In some studied samples also smaller amounts of quartz and clay minerals were observed.

\section{Fourier transform spectroscopy}

Results of FTIR indicate that high magnesium calcite is present in limestones of all investigated strata. It was identified in five samples (Table 1) (Stanienda 2005). High magnesium calcite is present in smaller amounts that low magnesium calcite. In lots of samples dolomite was also identified (Table 1).

The values of the $V_{3}$ absorption band of high-Mg calcite are as follows: 1433 and $1435 \mathrm{~cm}^{-1}$ for upper Biohermal limestone and $1428 \mathrm{~cm}^{-1}$ for limestones of other formations (lower Crinoidea limestone, upper Crinoidea limestone and lower Biohermal limestone) (Stanienda 2005).
The change of the $V_{3}$ value can indicate the variable content of magnesium in the crystals of high magnesium calcite. The increase in the $V_{3}$ value indicates the increase in the amount of $\mathrm{Mg}$ ions in the $\mathrm{Mg}$-calcite crystal structure. The values of the $V_{3}$ absorption band show a higher content of $\mathrm{Mg}$ in high magnesium calcite of upper Biohermal limestone in comparison with this carbonate phase of other limestone formations. The values of the $V_{3}$ absorption band of high$\mathrm{Mg}$-calcite are as follows- 1433 and $1435 \mathrm{~cm}^{-1}$ for upper Biohermal limestone and $1428 \mathrm{~cm}^{-1}$ for limestones of other formations (lower Crinoidea limestone, upper Crinoidea limestone and lower Biohermal limestone) (Stanienda 2005).

High-Mg calcite was also identified by the absorption band $V_{1}+V_{3}$, which presented values from 2517 to $2521 \mathrm{~cm}^{-1}$ (Table 1). In some samples there also occurred other absorption bands, typical for high-Mg calcite (Table 1). Apart from carbonate phases also quartz and clay minerals were identified. The results of FTIR confirmed the hypothesis of the presence of high-Mg calcite in studied limestones.

\section{X-ray diffraction}

$\mathrm{X}$-ray diffraction is usually used to determine crystal structure. I can refine the structure using Rietveld method, for example, or refine the lattice parameters, using the Le Bail method. The $d_{104}$ value of high-Mg calcite depends on $\mathrm{MgCO}_{3}$ content. According to Zhang et al. (2010), a value of $d_{104}-2.988 \AA$ is typical for high-Mg calcite with content of $\mathrm{MgCO}_{3}: 16.3 \mathrm{~mol} \%$, a value of $d_{104}-2.972 \AA$ for content of $\mathrm{MgCO}_{3}: 22.5 \mathrm{~mol} \%$. If the content of $\mathrm{MgCO}_{3}$ rises, the value of $d_{104}$ drops. Unstable calcite phases could also present the value of $d_{104}-2.964 \AA$ (Smyth and Ahrens 1997).

The results of the X-ray diffraction indicate that the peaks of high magnesium calcite show lower values than the peaks of low-Mg calcite but higher than the ones typical for dolomite (Table 2). High-Mg calcite was identified mainly based on the peaks typical for this carbonate phase (Table 2) (Stanienda 2006). The significant difference in the content of magnesium in high-Mg calcite of limestones from Karchowice Formation was not observed because the peak value of $d_{104}$ appearing in X-ray diffraction patterns of investigated limestones is in all samples the same: $2.990 \AA$ (100). With the increase of magnesium in high-Mg calcite, the peak value of $d_{104}$ drops. It was impossible to calculate definitely the cell parameters of high magnesium calcite since polymineral samples were analyzed. There was a small amount of high- $\mathrm{Mg}$ calcite in the investigated limestones. Low- $\mathrm{Mg}$ calcite and high-Mg calcite were mixed in rocks, so it was not possible to separate a single crystal from this mixture. On the basis of the peak values, mainly of $d_{104}$, visible in $\mathrm{X}$-ray diffraction patterns of the investigated limestones, $a_{0}$ and $c_{0}$ values were established according to ICDD card index 
Table 1 Results of the Fourier transform infrared spectroscopy (FTIR) $\left(\mathrm{cm}^{-1}\right)$ (Stanienda 2005)

\begin{tabular}{|c|c|c|c|c|c|}
\hline Type of limestone & Low-Mg calcite & High-Mg calcite & Dolomite & Quartz & Clay minerals \\
\hline $\begin{array}{l}\text { Lower Crinoidea limestone } \\
\text { (sample 7-content of } \mathrm{MgO} \text { : } \\
9.5 \% \text { ) }\end{array}$ & $\begin{array}{l}V_{4}=712.39 \\
V_{2}=848 \\
V_{2}=876.12 \\
V_{1}+V_{4}=1798.41 \\
\text { Other absorption bands-2599, } \\
\quad 2875.66 ; 2928.29 ; 2983.72 ; \\
3422.71\end{array}$ & $\begin{array}{l}V_{3}=1428.23 \\
V_{1}+V_{3}=2517.35\end{array}$ & $\begin{array}{l}V_{4}=728.77 \\
V_{1}+V_{4}=1822.95\end{array}$ & $\begin{array}{l}465.86 \\
779.33 \\
799.59 \\
1095.22\end{array}$ & $\begin{array}{l}570.08 \\
577.27 \\
604.41 \\
923.04 \\
965.14 \\
1047.34\end{array}$ \\
\hline $\begin{array}{l}\text { Lower Biohermal limestone } \\
\text { (sample } 1 \text {-content of } \mathrm{MgO} \text { : } \\
7.36 \% \text { ) }\end{array}$ & $\begin{array}{l}V_{4}=712.39 \\
V_{2}=847.94 \\
V_{2}=876.19 \\
V_{1}+V_{4}=1798.23 \\
V_{1}+V_{3}=2512.36 \\
\text { Other absorption bands- } \\
\quad 2587.82 ; 2875.01 ; 2946.62 ; \\
2983.263418 .49\end{array}$ & $V_{3}=1428.34$ & - & $\begin{array}{l}463.28 \\
515.05 \\
777.40 \\
798.69 \\
1094.38\end{array}$ & $\begin{array}{l}570.49 \\
604.58 \\
965.62 \\
1049.06 \\
1169.97\end{array}$ \\
\hline $\begin{array}{l}\text { Upper Crinoidea limestone } \\
\text { (sample } 22 \text {-content of } \\
\text { MgO: } 11.34 \% \text { ) }\end{array}$ & $\begin{array}{l}V_{4}=712.55 \\
V_{2}=848.37 \\
V_{2}=876.96 \\
V_{1}+V_{4}=1797.56 \\
\text { Other absorption bands- } \\
\quad 2519.87 ; 2577.21 ; 2876.87 ; \\
2984.23 ; 3448.5\end{array}$ & $\begin{array}{l}V_{3}=1434.81 \\
V_{1}+V_{3}=2519.87 \\
\text { Other absorption bands- } \\
\quad 2621.57 ; 2942.76\end{array}$ & $\begin{array}{l}V_{4}=728.77 \\
V_{2}=852.98 \\
V_{2}=880 \\
V_{1}+V_{4}=1818.13\end{array}$ & 1094.44 & $\begin{array}{l}570.45 \\
604.99 \\
1050.18\end{array}$ \\
\hline $\begin{array}{l}\text { Upper Biohermal limestone } \\
\text { (sample } 62-\text { content of } \\
\text { MgO: } 13.95 \% \text { ) }\end{array}$ & $\begin{array}{l}V_{4}=712.58 \\
V_{2}=848.18 \\
V_{2}=877.89 \\
V_{1}+V_{4}=1796.83 \\
\text { Other absorption bands- } \\
\text { 2583.96; 2877.64; } 2932.15 ; \\
2984.23 ; 3446.71\end{array}$ & $\begin{array}{l}V_{3}=1435.33 \\
V_{1}+V_{3}=2521.2 \\
\text { Other absorption bands- } \\
\quad 2625.43 ; 3021.85\end{array}$ & $\begin{array}{l}V_{4}=728.86 \\
V_{2}=853 \\
V_{1}+V_{4}=1821.98\end{array}$ & 1094.24 & $\begin{array}{l}569.06 \\
605.18 \\
1049.89\end{array}$ \\
\hline
\end{tabular}

(ICDD card index from the PDF-4+ database with number 04-008-806). These values are as follows: $a_{0}=4941 \AA$, $c_{0}=16,854 \AA$. These values are similar to the parameters established by Johnson (2002) $\left(a_{0}=4.942 \AA\right.$ and $c_{0}=16.85$ A).

Apart from carbonate phases with different magnesium contents (low-Mg calcite, high-Mg calcite and dolomite), quartz was also identified.

Results of X-ray diffraction confirmed the hypothesis of the high magnesium calcite presence in the Muschelkalk limestones of the Polish part of Germanic Basin.

\section{Microprobe measurements}

Results of microprobe measurements show that in samples of all formations three carbonate phases are present-low magnesium calcite, high-Mg calcite and dolomite. These phases are different in respect of $\mathrm{MgCO}_{3}$ content.

In lower Crinoidea limestone: Variability of mineral phases showing different amounts of magnesium is possible to observe in BSE image. The phases reveal different shades of grey. Fair grey characterizes low magnesium calcite. Grey is typical for high-Mg calcite and dark grey-for dolomite (Fig. 5A). It was confirmed by results of chemical analysis executed in selected points of microarea (Table 3). Micritic, xenomorphic crystals of high magnesium calcite form rock cement. Dolomite, sparry crystals are euhedral and rhombohedral in shape (Fig. 5A). In lower Crinoidea limestone, the content of $\mathrm{MgCO}_{3}$ in low-Mg calcite ranges from 1.02 to $8.22 \%$, in high-Mg calcite-from 22.82 to $33.11 \%$ and in dolomite-from 44.13 to $45.78 \%$ (Table 3). The low content of $\mathrm{MgCO}_{3}$ in the dolomite phase in comparison with the stoichiometric value for dolomite $\left(46.13 \% \mathrm{MgCO}_{3}, 13.18 \% \mathrm{Mg}\right)$ indicates that probably protodolomite is present in lower Crinoidea limestone. This non-stoichiometric, poorly ordered carbonate phase usually forms crystals euhedral and rhombohedral in shape (Boggs 2010; Morse and Mackenzie 1990; Tucker and Wright 1990). The amount of Ca in high magnesium calcite ranges from 30.30 to $36.06 \%, \mathrm{Mg}$ : from 6.52 to $9.46 \%$, C: from 7.80 to $8.80 \%$ and O: from 48.70 to $50.41 \%$. The median value of magnesium calculated for high-Mg calcite averages to $8.37 \%$ (29.30\% $\left.\mathrm{MgCO}_{3}\right)$. In protodolomite and high-Mg calcite the increased content of iron was observed (Table 3 ). The iron probably replaces magnesium in these carbonate phases. 
Table 2 Results of X-ray diffractometry

\begin{tabular}{|c|c|c|}
\hline Type of sample & Type of mineral & $\begin{array}{l}d_{\mathrm{hkl}} \text {-index of the lattice intervals of exposed parallel lattice planes system- } \hat{A} \\
(I) \text {-intensity of diffraction lines }\end{array}$ \\
\hline \multirow[t]{3}{*}{ Lower Crinoidea limestone (sample 7) } & Low-Mg calcite & $\begin{array}{l}3.865(12), 3.042(100), 2.855(3), 2.495(12), 2.287(15), 2.095(15), 1.928(5), \\
1.914(15), 1.876(15), 1.627(4), 1.603(8), 1.525(5), 1.513(4), 1.473(2), 1.440 \\
(5), 1.338(2), 1.235(1), 1.180(3), 1.154(3), 1.142(1), 1.062(1), 1.046(3), \\
1.035(3)\end{array}$ \\
\hline & High-Mg calcite & $\begin{array}{l}2.990(100), 2.570(2), 2.260(15), 1.857(15), 1.471(2), 1.423(3), 1.410(3), 1.249 \\
\quad(1), 1.193(3), 1.130(1), 1.013(2)\end{array}$ \\
\hline & Dolomite & $\begin{array}{l}2.895(100), 2.684(4), 2.544(3), 2.410(7), 2.195(15), 2.069(3), 2.027(10), 1.807 \\
(10), 1.789(12), 1.470(2), 1.433(1), 1.392(2), 1.296(2), 1.273(2), 1.202(3), \\
1.125(1), 1.111(1), 1.009(4), 1.0014(5), 0.9766(3), 0.9664(5), 0.9642(1)\end{array}$ \\
\hline \multirow[t]{4}{*}{ Upper Crinoidea limestone (sample 15) } & Low-Mg calcite & $\begin{array}{l}3.870(12), 3.041(100), 2.837(3), 2.496(12), 2.288(15), 2.096(15), 1.925(5), \\
1.912(15), 1.876(15), 1.626(4), 1.604(8), 1.522(5), 1.513(4), 1.473(2), 1.440 \\
(5), 1.234(1), 1.180(3), 1.154(3), 1.143(1), 1.046(3), 1.035(3), 0.9839(1)\end{array}$ \\
\hline & High-Mg calcite & $\begin{array}{l}2.990(100), 2.570(2), 1.857(15), 1.471(2), 1.422(3), 1.410(3), 1.247(1), 1.190 \\
\quad(3), 1.130(1), 1.063(1), 1.042(1), 1.013(2)\end{array}$ \\
\hline & Dolomite & $\begin{array}{l}2.893(100), 2.020(10), 1.470(2), 1.340(1), 1.298(2), 1.099(1), 0.9756(3) \\
0.9645(5)\end{array}$ \\
\hline & Quartz & $3.355(100)$ \\
\hline \multirow[t]{4}{*}{ Upper Crinoidea limestone (sample 22) } & Low-Mg calcite & $\begin{array}{l}3.868(12), 3.039(100), 2.853(3), 2.497(12), 2.286(15), 2.096(15), 1.929(5), \\
1.914(15), 1.877(15), 1.626(4), 1.604(8), 1.521(5), 1.517(4), 1.441(5), 1.335 \\
(2), 1.178(3), 1.153(3), 1.048(3)\end{array}$ \\
\hline & High-Mg calcite & $\begin{array}{l}2.990(100), 2.576(2), 2.260(15), 1.470(2), 1.423(3), 1.249(1), 1.190(3), 1.160 \\
\quad(3), 1.130(1), 1.010(2)\end{array}$ \\
\hline & Dolomite & $\begin{array}{l}4.040(1), 3.715(4), 3.681(4), 2.899(100), 2.680(4), 2.544(3), 2.410(7), 2.198 \\
(15), 2.069(3), 2.018(10), 1.800(10), 1.790(12), 1.570(2), 1.546(4), 1.467(2), \\
1.414(3), 1.388(15), 1.297(2), 1.271(2), 1.240(5), 1.203(3), 1.111(5), 1.069 \\
(1), 1.0098(4), 1.0018(5), 0.9754(3), 0.9661(1), 0.9547(1)\end{array}$ \\
\hline & Quartz & $3.340(100)$ \\
\hline \multirow[t]{3}{*}{ Upper Biohermal limestone (sample 62) } & Low-Mg calcite & $\begin{array}{l}3.862(12), 3.044(100), 2.495(12), 2.285(15), 2.095(15), 1.927(5), 1.911(15), \\
\quad 1.875(15), 1.605(8), 1.525(5), 1.339(2), 1.152(3), 1.042(3)\end{array}$ \\
\hline & High-Mg calcite & $\begin{array}{l}2.990(100), 2.570(2), 2.260(15), 1.854(15), 1.470(2), 1.420(3), 1.410(3), 1.190 \\
\quad(3), 1.130(1), 1.013(2)\end{array}$ \\
\hline & Dolomite & $\begin{array}{l}3.700(4), 2.896(100), 2.680(4), 2.547(3), 2.412(7), 2.197(15), 2.066(3), 2.019 \\
(10), 1.808(10), 1.789(12), 1.547(4), 1.468(2), 1.431(1), 1.389(15), 1.296(2), \\
1.237(5), 1202(3), 1.168(1), 1.111(5), 1.096(1), 1.068(1), 1.0094(4), 1.0015 \\
(5), 0.9744(3), 0.9627(5)\end{array}$ \\
\hline
\end{tabular}

The results of the analyses allowed to determine a high magnesium calcite chemical formula of lower Crinoidea limestone: $\left(\mathrm{Ca}_{0.87-0.80}, \mathrm{Mg}_{0.13-0.20}\right) \mathrm{CO}_{3}$.

In lower Biohermal limestone: low-Mg calcite and high$\mathrm{Mg}$ calcite form the micritic rock mass. The mixture of these carbonate phases is visible in BSE image as a fair grey mass (Fig. 5B), but there is no difference in colour shades between low-Mg calcite and high-Mg calcite. Sparry dark grey dolomite crystals (Table 4) are euhedral and rhombohedral in shape (Fig. 5B). Like in lower Crinoidea limestone, also in these rocks protodolomite is probably present. The crystals of this carbonate phase are similar to protodolomite crystals of lower Crinoidea limestone. The difference in the magnesium content in carbonate phases is only possible to observe in Table 4 which includes the results of the chemical analysis executed in selected points of the microarea. In lower Biohermal limestone the content of $\mathrm{MgCO}_{3}$ in low magnesium calcite ranges from 0.42 to $1.19 \%$, in high- $\mathrm{Mg}$ calcite-from 29.61 to $36.89 \%$ (Table 4). The amount of $\mathrm{Ca}$ in high magnesium calcite ranges from 33.46 to $36.18 \%$, $\mathrm{Mg}$ : from 8.46 to $10.54 \%, \mathrm{C}$ : from 7.95 to $10.28 \%$ and O: from 43.51 to $46.86 \%$. The median value of magnesium calculated for high-Mg calcite averages $9.5 \%\left(33.25 \% \mathrm{MgCO}_{3}\right)$. Protodolomite was also identified in this limestone. It is represented by crystals in which the content of $\mathrm{MgCO}_{3}$ ranges from 40.60 to $43.92 \%$ (Table 4). The content of $\mathrm{MgCO}_{3}$ in protodolomite is lower than the stoichiometric value for dolomite- $46.13 \%$.

As in the previous sample, also in this case the increased content of iron was observed in high-Mg calcite and protodolomite (Table 4). The iron probably replaces magnesium in these carbonate phases. 

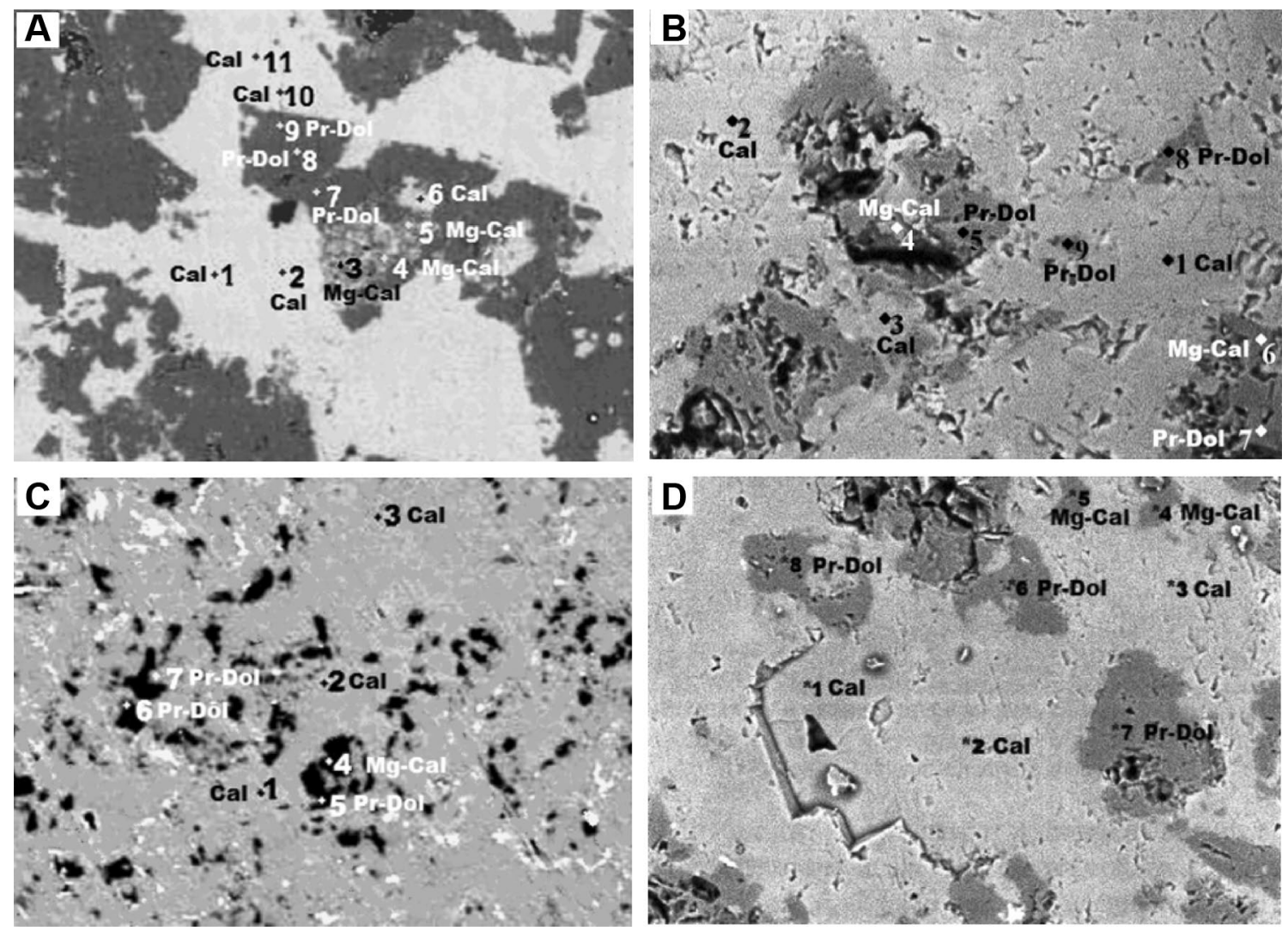

Fig. 5 A BSE image of an lower Crinoidea limestone (sample 7) (Stanienda 2004, 2011). Magn. $\times 1500,1-11$-points of chemical analysis. Cal-low-Mg calcite; Mg-Cal—high-Mg calcite; Pr-Dol-protodolomite. B BSE image of an Lower Biohermal Limestone (sample 2). Magn. $\times 600,1-9$-points of chemical analysis. Cal-low-Mg calcite; $\mathrm{Mg}$-Cal—high-Mg calcite; Pr-Dol—protodolomite. C BSE

image of an upper Crinoidea limestone (sample 15) (Stanienda 2004, 2011). Magn. $\times 1000,1-7$-points of chemical analysis. Cal-low-Mg calcite; Mg-Cal—high-Mg calcite; Pr-Dol—protodolomite. D BSE image of an upper Biohermal limestone (sample 41). Magn. $\times 1500$, 1-8-points of chemical analysis (Stanienda 2006). Cal-low-Mg calcite; $\mathrm{Mg}-\mathrm{Cal}$ - high-Mg calcite; $\mathrm{Pr}-\mathrm{Dol}$ - protodolomite

The results of these analyses allowed to determine a high magnesium calcite chemical formula of lower Biohermal limestone: $\left(\mathrm{Ca}_{0.83-0.75}, \mathrm{Mg}_{0.17-0.25}\right) \mathrm{CO}_{3}$.

Upper Crinoidea limestone: Is also composed of three carbonate phases. Low-Mg calcite and high-Mg calcite form the micritic rock mass, similar to the rock mass of lower Biohermal limestone. In BSE image, it is not possible to distinguish these carbonate phases based on the shades of grey colour (Fig. 5C), similarly to the previous sample. Small sparry dolomite crystals, almost black in colour in this sample, are euhedral and rhombohedral in shape (Fig. 5C). The difference in the magnesium content in the carbonate phases may be seen in Table 5, which presents the results of chemical analysis executed in the selected points of the microarea. In upper Crinoidea limestone the content of $\mathrm{MgCO}_{3}$ in low magnesium calcite ranges from 1.43 to $1.85 \%$, in high- $\mathrm{Mg}$ calcite-it is $30.52 \%$ and in dolomite phase-from 43.33 to $45.57 \%$ (Table 5). In upper Crinoidea limestones, protodolomite is also present. High magnesium calcite of upper Crinoidea limestone is composed of $29.30 \%$ of $\mathrm{Ca}, 8.72 \%$

of $\mathrm{Mg}, 10.08 \%$ of C and $50.09 \%$ of O. Sodium occurred in the upper Crinoidea limestone may come from diagenetic fluids. The occurrence of $\mathrm{Ba}$ and $\mathrm{Sr}$ in rocks confirms the presence of the aragonite phase in the primary carbonate sediment. The results allowed to determine a high magnesium calcite chemical formula of upper Crinoidea limestone: $\left(\mathrm{Ca}_{0.81}, \mathrm{Mg}_{0.19}\right) \mathrm{CO}_{3}$.

Three carbonate phases, varying in amount of $\mathrm{MgCO}_{3}$, were also identified in upper Biohermal limestone. Low-Mg calcite and high-Mg calcite form, the micritic rock mass. In BSE image of this limestone there is no difference in the colour shades of calcite phases (Fig. 5D). They form fair grey mass. Dolomite phase is easy to distinguish in BSE image. It forms dark grey, sparry crystals which are euhedral and rhombohedral in shape (Fig. 5D). Looking at the results of the chemical analysis (Table 6), one can observe the difference in magnesium content in the carbonate phases, as well as in this limestone. In upper Biohermal limestone the content of $\mathrm{MgCO}_{3}$ in low-Mg calcite ranges from 0.14 to $0.21 \%$, in high-Mg calcite-from 30.76 to $34.02 \%$ and in dolomite 


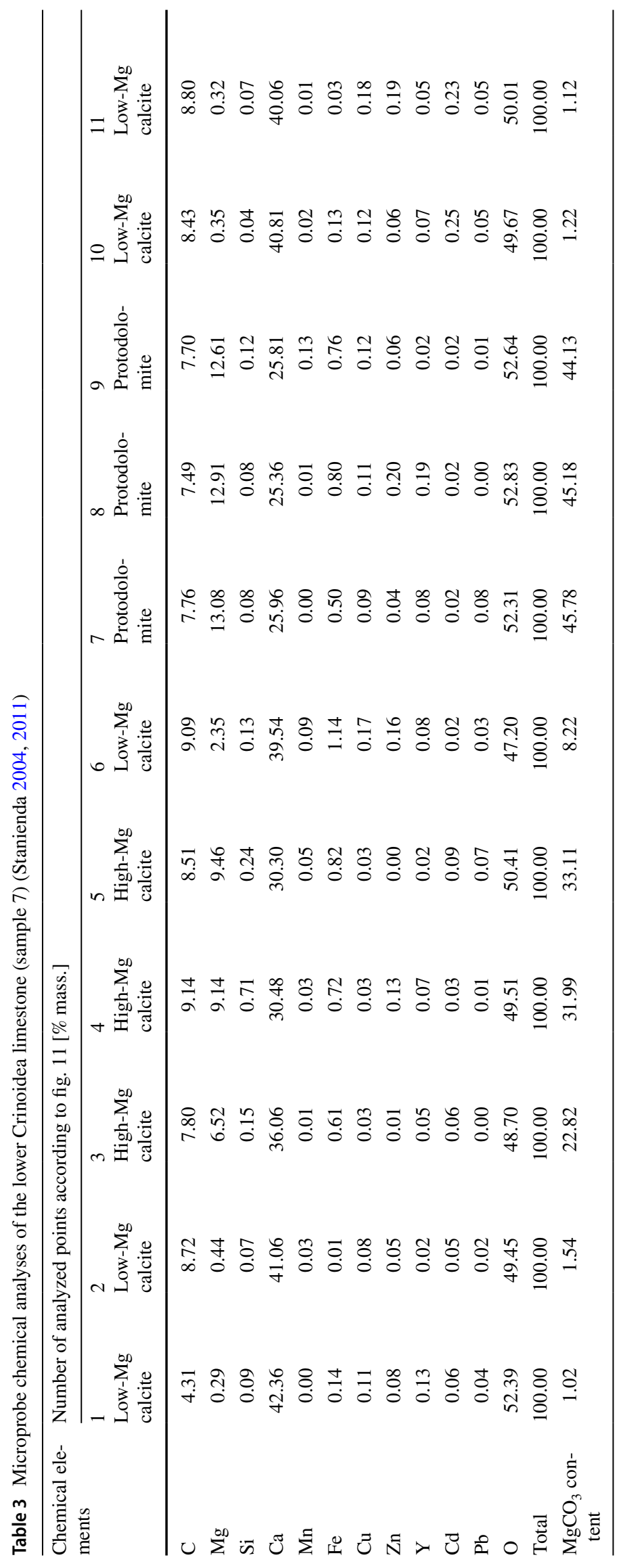


Table 4 Microprobe chemical analyses of the lower Biohermal limestone (sample 1)

\begin{tabular}{|c|c|c|c|c|c|c|c|c|c|}
\hline \multirow{2}{*}{$\begin{array}{l}\text { Chemical } \\
\text { elements }\end{array}$} & \multicolumn{9}{|c|}{ Numbers of analyzed points according to fig. 12 [\% mass.] } \\
\hline & $\begin{array}{l}1 \\
\text { Low-Mg } \\
\text { calcite }\end{array}$ & $\begin{array}{l}2 \\
\text { Low-Mg } \\
\text { calcite }\end{array}$ & $\begin{array}{l}3 \\
\text { Low-Mg } \\
\text { calcite }\end{array}$ & $\begin{array}{l}4 \\
\text { High-Mg } \\
\text { calcite }\end{array}$ & $\begin{array}{l}5 \\
\text { Protodolo- } \\
\text { mite }\end{array}$ & $\begin{array}{l}6 \\
\text { High-Mg } \\
\text { calcite }\end{array}$ & $\begin{array}{l}7 \\
\text { Protodolo- } \\
\text { mite }\end{array}$ & $\begin{array}{l}8 \\
\text { Protodolo- } \\
\text { mite }\end{array}$ & $\begin{array}{l}9 \\
\text { Protodo- } \\
\text { lomite }\end{array}$ \\
\hline C & 11.09 & 13.10 & 12.77 & 10.28 & 12.03 & 7.95 & 10.95 & 11.83 & 12.91 \\
\hline $\mathrm{Mg}$ & 0.34 & 0.12 & 0.29 & 8.46 & 11.70 & 10.54 & 11.98 & 12.55 & 11.60 \\
\hline $\mathrm{Si}$ & 0,06 & 0.14 & 0.09 & 0.22 & 0.24 & 0.25 & 0.22 & 1.46 & 0.02 \\
\hline $\mathrm{Ca}$ & 40.06 & 36.84 & 37.68 & 33.46 & 24.93 & 36.18 & 27.54 & 21.91 & 21.90 \\
\hline $\mathrm{Fe}$ & 0.11 & 0.02 & 0.12 & 0.72 & 0.78 & 1.57 & 0.71 & 3.05 & 0.98 \\
\hline $\mathrm{O}$ & 48.34 & 49.78 & 49.05 & 46.86 & 50.32 & 43.51 & 48.60 & 49.20 & 52.59 \\
\hline Total & 100.00 & 100.00 & 100.00 & 100.00 & 100.00 & 100.00 & 100.00 & 100.00 & 100.00 \\
\hline $\begin{array}{l}\mathrm{MgCO}_{3} \\
\text { content }\end{array}$ & 1.19 & 0.42 & 1.01 & 29.61 & 40.95 & 36.89 & 41.93 & 43.92 & 40.60 \\
\hline
\end{tabular}

Table 5 Microprobe chemical analyses of the upper Crinoidea limestone (sample 15) (Stanienda 2004, 2011)

\begin{tabular}{|c|c|c|c|c|c|c|c|}
\hline \multirow[t]{2}{*}{ Chemical elements } & \multicolumn{7}{|c|}{ Number of analyzed points according to Fig. 13 [\% mass.] } \\
\hline & $\begin{array}{l}1 \\
\text { Low-Mg calcite }\end{array}$ & $\begin{array}{l}2 \\
\text { Low-Mg calcite }\end{array}$ & $\begin{array}{l}3 \\
\text { Low-Mg calcite }\end{array}$ & $\begin{array}{l}4 \\
\text { High-Mg calcite }\end{array}$ & $\begin{array}{l}5 \\
\text { Protodolomite }\end{array}$ & $\begin{array}{l}6 \\
\text { Protodolomite }\end{array}$ & $\begin{array}{l}7 \\
\text { Protodolomite }\end{array}$ \\
\hline $\mathrm{C}$ & 10.04 & 10.02 & 9.99 & 10.08 & 6.11 & 6.48 & 8.13 \\
\hline $\mathrm{Na}$ & 0.98 & 0.93 & 0.95 & 1.24 & 0.93 & 1.02 & 1.19 \\
\hline $\mathrm{Mg}$ & 0.41 & 0.53 & 0.45 & 8.72 & 12.38 & 13.02 & 12.68 \\
\hline $\mathrm{Al}$ & 0.05 & 0.05 & 0.05 & 0.09 & 0.07 & 0.06 & 0.05 \\
\hline $\mathrm{Si}$ & 0.07 & 0.07 & 0.06 & 0.12 & 0.09 & 0.06 & 0.08 \\
\hline $\mathrm{Ca}$ & 41.16 & 40.86 & 41.17 & 29.30 & 27.69 & 27.29 & 27.63 \\
\hline $\mathrm{Mn}$ & 0.04 & 0.09 & 0.04 & 0.01 & 0.03 & 0.05 & 0.16 \\
\hline $\mathrm{Fe}$ & 0.02 & 0.21 & 0.21 & 0.27 & 0.37 & 0.36 & 0.18 \\
\hline $\mathrm{Sr}$ & 0.05 & 0.00 & 0.03 & 0.02 & 0.13 & 0.02 & 0.05 \\
\hline $\mathrm{Ba}$ & 0.01 & 0.02 & 0.10 & 0.06 & 0.17 & 0.09 & 0.07 \\
\hline $\mathrm{O}$ & 47.17 & 47.22 & 46.95 & 50.09 & 52.03 & 51.55 & 49.78 \\
\hline Total & 100.00 & 100.00 & 100.00 & 100.00 & 100.00 & 100.00 & 100.00 \\
\hline $\mathrm{MgCO}_{3}$ content & 1.43 & 1.85 & 1.57 & 30.52 & 43.33 & 45.57 & 44.38 \\
\hline
\end{tabular}

Table 6 Microprobe chemical analyses of the upper Biohermal limestone (sample 41) (Stanienda 2006)

\begin{tabular}{|c|c|c|c|c|c|c|c|c|}
\hline \multirow{2}{*}{$\begin{array}{l}\text { Chemical ele- } \\
\text { ments }\end{array}$} & \multicolumn{8}{|c|}{ Number of analyzed points according to Fig. 14 [\% mass.] } \\
\hline & $\begin{array}{l}1 \\
\text { Low-Mg } \\
\text { calcite }\end{array}$ & $\begin{array}{l}2 \\
\text { Low-Mg } \\
\text { calcite }\end{array}$ & $\begin{array}{l}3 \\
\text { Low-Mg } \\
\text { calcite }\end{array}$ & $\begin{array}{l}4 \\
\text { High-Mg } \\
\text { calcite }\end{array}$ & $\begin{array}{l}5 \\
\text { High-Mg } \\
\text { calcite }\end{array}$ & $\begin{array}{l}6 \\
\text { Protodolomite }\end{array}$ & $\begin{array}{l}7 \\
\text { Protodolomite }\end{array}$ & $\begin{array}{l}8 \\
\text { Protodolomite }\end{array}$ \\
\hline $\mathrm{C}$ & 11.16 & 12.19 & 12.21 & 13.00 & 12.83 & 12.94 & 12.88 & 13.12 \\
\hline $\mathrm{Mg}$ & 0.04 & 0.06 & 0.05 & 8.79 & 9.72 & 12.48 & 12.22 & 12.12 \\
\hline $\mathrm{Si}$ & 0.00 & 0.00 & 0.00 & 0.00 & 0.00 & 0.00 & 0.00 & 0.00 \\
\hline $\mathrm{Ca}$ & 40.19 & 39.40 & 39.34 & 26,18 & 26.10 & 22.70 & 23.05 & 22.48 \\
\hline $\mathrm{Fe}$ & 0.00 & 0.00 & 0.00 & 0.81 & 0.24 & 0.10 & 0.21 & 0.27 \\
\hline $\mathrm{Y}$ & 0.01 & 0.08 & 0.09 & 0.01 & 0.00 & 0.00 & 0.00 & 0.00 \\
\hline $\mathrm{O}$ & 48.60 & 48.27 & 48.31 & 51.21 & 51.11 & 51.78 & 51.64 & 52.01 \\
\hline Total & 100.00 & 100.00 & 100.00 & 100.00 & 100.00 & 100.00 & 100.00 & 100.00 \\
\hline $\begin{array}{l}\mathrm{MgCO}_{3} \text { con- } \\
\text { tent }\end{array}$ & 0.14 & 0.21 & 0.17 & 30.76 & 34.02 & 43.68 & 42.77 & 42.42 \\
\hline
\end{tabular}


phase-from 42.42 to $43.68 \%$ (Table 6). However, the dolomite phase is characterized by a lower content of $\mathrm{MgCO}_{3}$ in comparison with the stoichiometric value for dolomite, so this mineral should be treated as protodolomite. The amount of $\mathrm{Ca}$ in high magnesium calcite of upper Crinoidea limestone ranges from 26.10 to $26.18 \%, \mathrm{Mg}$ : from 8.79 to $9.72 \%$, C: from 12.83 to $13.00 \%$ and O: from 51.11 to $51.21 \%$. The median value of magnesium calculated for high-Mg calcite averages to $9.25 \%$ ( $32.37 \% \mathrm{MgCO}_{3}$ ). Iron was not identified in the analyzed limestone sample with low-Mg calcite. Small amounts of this element occur in protodolomite and high-Mg calcite (Table 6). The iron probably replaces magnesium in these carbonate phases.

On the basis of the results, it was possible to determine a high magnesium calcite chemical formula of upper Biohermal limestone: $\left(\mathrm{Ca}_{0.78-0.77}, \mathrm{Mg}_{0.22-0.23}\right) \mathrm{CO}_{3}$.

On the basis of microprobe measurement results it can be concluded that three carbonate phases, different in magnesium content, built Triassic limestone of the Polish part of the Germanic Basin. The first one is low magnesium calcite with the content of $\mathrm{Mg}$ of about $1.81 \%$ (6.33\% of $\mathrm{MgCO}_{3}$ ). The second phase is high-Mg calcite with the content of $\mathrm{Mg}$ changing from about 3.92-9.65\% $\left(\mathrm{MgCO}_{3}\right.$ : from 13.72 to $33.77 \%$ ). The third one is the dolomite phase which is characterized by varying content of $\mathrm{MgCO}_{3}$, from very low amounts of about $35.88-44.33 \%$ of $\mathrm{MgCO}_{3}$. These values are lower than the stoichiometric value for dolomite $46.13 \%$ $\mathrm{MgCO}_{3}(13.18 \% \mathrm{Mg})$. Therefore, this mineral phase is recognized as protodolomite.

The results of microprobe measurements confirmed the hypothesis of the presence of high-Mg calcite in studied Triassic limestones. On the basis of these results it was possible to determine the variability of $\mathrm{Mg}$ content in high-Mg calcite crystals. The results of the microprobe measurements indicate that beside of echinoderms the high-Mg calcite is also observed in other bioclasts. However, this phase most often built micritic cement (Fig. 5A, C).

\section{Mapping executed with the use of the microprobe measurements method}

Mapping was executed to differentiate the types of high$\mathrm{Mg}$ calcite and changes in the magnesium content inside single crystals. The analysis was carried out with the use of the EDS method. Measurements were executed in carbonate ground mass. The results of mapping show that three carbonate phases are present in the investigated samples: low magnesium calcite, high-Mg calcite and dolomite. It confirms the results of the microprobe measurements carried out using the WDS method.

In the microarea of lower Crinoidea limestone (sample 7), the analysis was executed in six points (Fig. 6A, Table 7). Three points $(1,2$, and 3$)$ were localized in the dark grey crystal of the carbonate phase rich in magnesium and other three points $(4,5$ and 6$)$ in the zone of fair grey rock mass built of carbonate phase and characterized by low content of magnesium (Fig. 6A).

The results allowed to show that the dark grey crystals represent dolomite. The analyses in points 1,2 and 3 were executed inside a single crystal. There are no great differences in $\mathrm{Ca}$ and $\mathrm{Mg}$ content in the crystal of the dolomite phase (the amount of Ca ranges from 23.60 to $24.20 \%$ and $\mathrm{Mg}$ : from 12.10 to $12.70 \%$ ) (Table 7). However, the content of $\mathrm{Mg}$ in this phase is lower than the stoichiometric value for dolomite- $13.18 \%$ (46.13\% of $\mathrm{MgCO}_{3}$ ). It indicates the presence of a dolomite phase rich in $\mathrm{Ca}$ (probably protodolomite). The results of the measurements carried out in points 4,5 and 6 show that fair grey rock mass is built of low- $\mathrm{Mg}$ calcite. The amount of $\mathrm{Ca}$ in the low magnesium calcite phase ranges from 38.80 to $41.50 \%$ and $\mathrm{Mg}$ : only from 0.10 to $0.90 \%$ (Table 7). The results of mapping executed in the microarea of lower Crinoidea limestone using microprobe measurements with application of the EDS method confirm the results of the microprobe measurement carried out with use of the WDS method.

In the first microarea of the upper Biohermal limestone (sample 41) the analysis was executed in ten points (Fig. 6B, Table 8$)$. Six points $(1,2,4,5,6$ and 10) were localized in the fair grey rock mass and four inside the dark grey crystals of a carbonate phase rich in magnesium (Fig. 6B). Point 3 was localized in the center of a small euhedral crystal and points 7,8 and 9 also inside of a single euhedral crystal, point 8 -in the center of the crystal and points 7 and $9-$ near the edges of the rhombohedron. The results tests show that in points 2, 5, 6 and 10 low-Mg calcite was identified. The amount of $\mathrm{Ca}$ in the low-Mg calcite phase ranges from 26.20 to $38.20 \%, \mathrm{Mg}$ : from 0.10 to $5.00 \%$, C: from 11.50 to $13.50 \%$ and O: from 50.20 to $57.50 \%$ (Table 8). High$\mathrm{Mg}$ calcite occurs in points 1 and 4 . The amount of $\mathrm{Ca}$ in high- $\mathrm{Mg}$ calcite phase ranges from 18.20 to $33.60 \%, \mathrm{Mg}$ : from 8.00 to $10.20 \%$, C: from 11.10 to $15.00 \%$ and O: from 47.30 to $55.40 \%$ (Table 8 ). The calcite phases are mixed in the micritic rock mass so it was not possible to observe the changes in $\mathrm{Mg}$ content inside of the high magnesium calcite crystals. The amount of $\mathrm{Ca}$ in the dolomite phase ranges from 22.20 to $24.30 \%, \mathrm{Mg}$ : from 12.20 to $13.30 \%$, C: from 12.10 to $12.70 \%$ and O: from 53.00 to $53.90 \%$ (Table 8). The differences in $\mathrm{Ca}$ and $\mathrm{Mg}$ content in points 7, 8 and 9 were observed. These points were situated inside a single crystal. The value of magnesium content is particularly important. In point 8 , situated in the centre of crystal, the value is $13.30 \%$ (46.55\% of $\mathrm{MgCO}_{3}$ ). It indicates the presence of typical ordered dolomite. But the values of $\mathrm{Mg}$ in points 7 and 9 are lower than the stoichiometric value for dolomite. They are characteristic rather for protodolomite. Because of these results, it is very difficult to say if the crystal for which the 

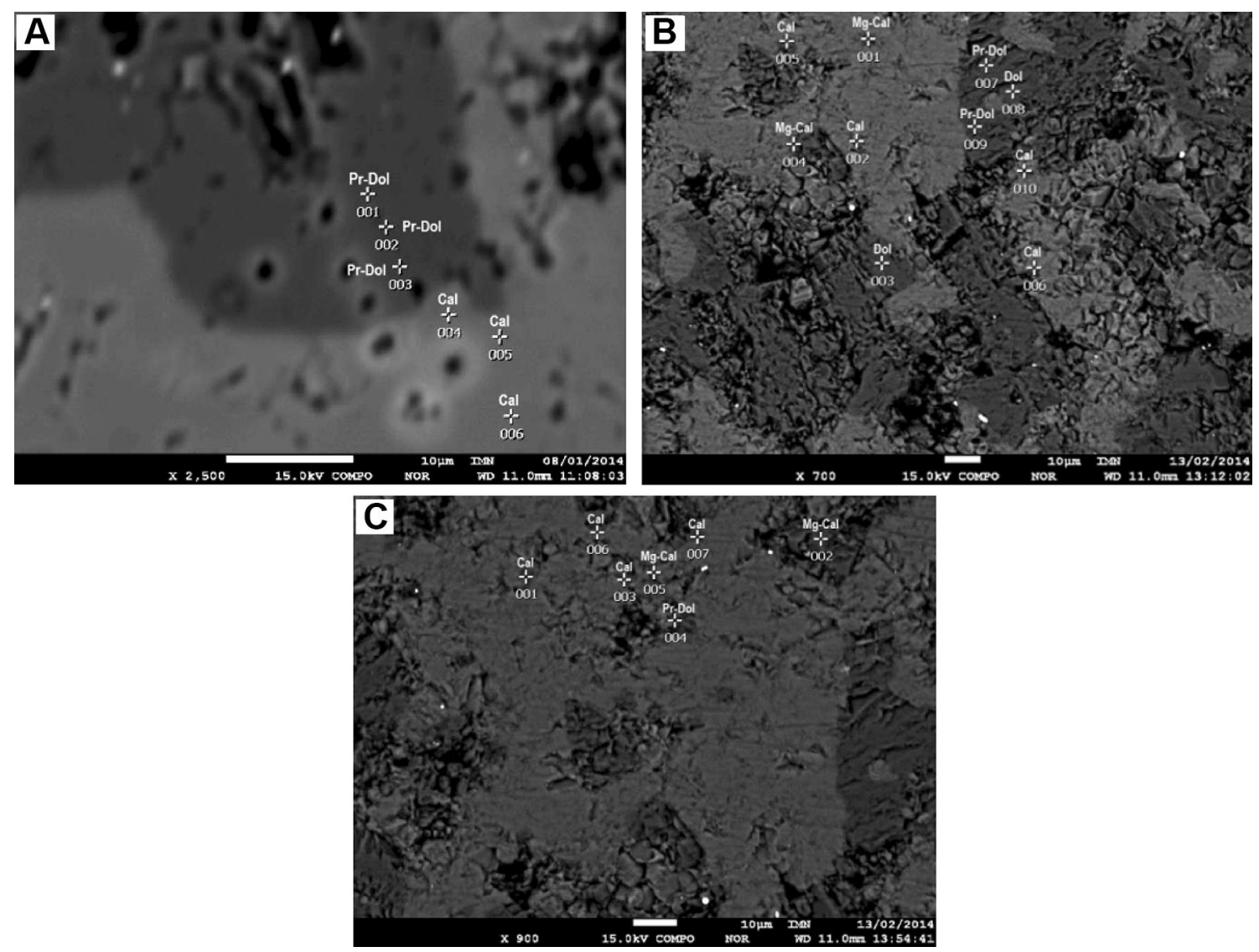

Fig. 6 A BSE image of an lower Crinoidea limestone (sample 7). Magn. $\times 2500,1-6$-points of chemical analysis. Cal-low-Mg calcite; Pr-Dol-protodolomite. B BSE image of an upper Biohermal limestone (sample 41). Magn. $\times 700,1-10$-points of chemical analysis. $\mathrm{Cal}-$ low-Mg calcite; $\mathrm{Mg}-\mathrm{Cal}$ - high-Mg calcite; Pr-Dol—protodolo- mite; Dol—ordered dolomite. C. BSE image of an Upper Biohermal Limestone (sample 41). Magn. $\times 900,1-7$-points of chemical analysis. Cal—low-Mg calcite; Mg-Cal—high-Mg calcite; Pr-Dol—protodolomite

Table 7 Microprobe chemical analyses in the microarea of the lower Crinoidea limestone (sample 7)

\begin{tabular}{|c|c|c|c|c|c|c|}
\hline \multirow[t]{2}{*}{ Chemical elements } & \multicolumn{6}{|c|}{ Number of analyzed points according to Fig. 15 [\% mass.] } \\
\hline & $\begin{array}{l}1 \\
\text { Protodolomite }\end{array}$ & $\begin{array}{l}2 \\
\text { Protodolomite }\end{array}$ & $\begin{array}{l}3 \\
\text { Protodolomite }\end{array}$ & $\begin{array}{l}4 \\
\text { Low-Mg calcite }\end{array}$ & $\begin{array}{l}5 \\
\text { Low-Mg calcite }\end{array}$ & $\begin{array}{l}6 \\
\text { Low-Mg calcite }\end{array}$ \\
\hline $\mathrm{C}$ & 10.10 & 9.80 & 8.90 & 11.60 & 10.00 & 10.20 \\
\hline $\mathrm{Mg}$ & 12.30 & 12.10 & 12.70 & 0.90 & 0.30 & 0.10 \\
\hline $\mathrm{Ca}$ & 24.00 & 23.60 & 24.20 & 38.80 & 41.50 & 40.80 \\
\hline $\mathrm{Fe}$ & 0.60 & 0.60 & 0.60 & 0.10 & 0.10 & 0.00 \\
\hline $\mathrm{O}$ & 53.00 & 53.90 & 53.60 & 48.60 & 48.10 & 48.90 \\
\hline Total & 100.00 & 100.00 & 100.00 & 100.00 & 100.00 & 100.00 \\
\hline $\mathrm{MgCO}_{3}$ content & 43.05 & 42.35 & 44.45 & 3.15 & 1.05 & 0.35 \\
\hline
\end{tabular}

analysis was carried out in points 7,8 and 9 is protodolomite as characterized by varying content of magnesium inside the crystal or if it is dedolomite in which in the center of the crystal the value of $\mathrm{Mg}$ is almost stoichiometric for dolomite and in the edge zones it is lower, which was caused by reduction during the process of dedolomitization. According to the results of the microprobe measurements executed using the WDS method, it could be rather protodolomite as characterized by varying $\mathrm{Mg}$ content in different zones of the crystal.

In the second microarea of the upper Biohermal limestone (sample 41), the analysis was executed in seven points 


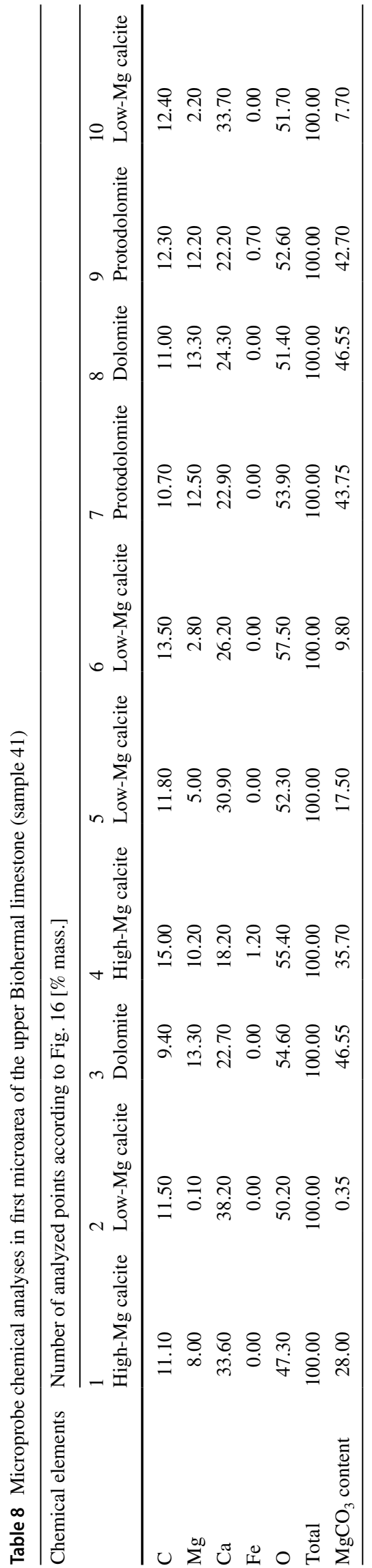

(Fig. 6C, Table 9). Four points (1, 3, 6 and 7) were localized in the fair grey rock mass and three inside dark grey crystals of a carbonate phase rich in magnesium (Fig. 6C). Point 2 was localized in the center of a bigger euhedral dark grey crystal and points 4 and 5 inside a single very small dark grey crystal. The results of the tests show that in points 1 , 3, 6 and 7 low-Mg calcite was identified. The amount of $\mathrm{Ca}$ in low-Mg calcite phase ranges from 32.60 to $36.80 \%$, $\mathrm{Mg}$ : from 2.70 to $4.40 \%$, C: from 10.40 to $12.70 \%$ and O: from 46.70 to $51.50 \%$ (Table 9). High-Mg calcite occurs in points 2 and 5 . The amount of $\mathrm{Ca}$ in the high-Mg calcite phase ranges from 29.10 to $29.40 \%, \mathrm{Mg}$ : from 7.30 to $9.80 \%, \mathrm{C}$ : from 7.90 to $12.00 \%$ and O: from 46.40 to $51.30 \%$ (Table 9). The high-Mg calcite identified in point 2 forms an euhedral crystal, rhombohedral in shape and the high- $\mathrm{Mg}$ calcite determined in point 5 forms micritic grains mixed with micritic grains of low-Mg calcite. Point 2 was probably localized inside a small high-Mg calcite inclusion, located in the centre of the dolomite crystal. It is also possible that this point was situated inside a protodolomite crystal. Like in the first microarea of upper Biohermal limestone, also in this one it is not possible to observe the distribution of $\mathrm{Mg}$ and the changes of content of this element inside a single high$\mathrm{Mg}$ calcite crystal. Point 4 was situated inside a dolomite phase. The amount of $\mathrm{Ca}$ in the dolomite phase is $19.20 \%$, $\mathrm{Mg}$ : from $11.00 \%, \mathrm{C}: 12.70 \%$ and O: $56.10 \%$ (Table 9). The value of the $\mathrm{Mg}$ content in the dolomite phase indicates that in this microarea of upper Biohermal limestone protodolomite is also present.

\section{ICP AES spectroscopy}

ICP AES spectroscopy was executed mainly to establish median average contents of $\mathrm{Ca}$ and $\mathrm{Mg}$ elements in the investigated limestones, and the amounts of $\mathrm{Fe}, \mathrm{Mn}, \mathrm{Sr}$ and $\mathrm{Ba}$ elements (Table 10). The content of $\mathrm{Ca}$ ranges from $27.30 \%$ in upper Crinoidea limestone to $32.90 \%$ in upper Biohermal limestone, $\mathrm{Mg}$ : from $7.00 \%$ in lower Crinoidea limestone to $9.10 \%$ in upper Biohermal limestone, Fe: from $0.19 \%$ in upper Crinoidea limestone to $0.25 \%$ in lower Crinoidea limestone, $\mathrm{Mn}$ : from $430 \mathrm{ppm}$ in lower Biohermal limestone to $550 \mathrm{ppm}$ in upper Biohermal limestone, $\mathrm{Sr}$ : from $120 \mathrm{ppm}$ in lower Biohermal limestone to $190 \mathrm{ppm}$ in upper Biohermal limestone and Ba: from 105 ppm in lower Biohermal limestone to $170 \mathrm{ppm}$ in upper Biohermal limestone. The results of the study show that the analyzed rocks are built of high-Mg calcite, which is further confirmed by high Fe content. Iron usually substitutes magnesium in carbonate minerals, which are rich in this element. The values of $\mathrm{Mg}$ content indicate the presence of high- $\mathrm{Mg}$ calcite in the limestones of the Polish part of the Germanic Basin. Probably manganese also substitutes other chemical elements in the carbonate phases. The presence of $\mathrm{Sr}$ and $\mathrm{Ba}$ 
Table 9 Microprobe chemical analyses in the second microarea of the upper Biohermal limestone (sample 41)

\begin{tabular}{|c|c|c|c|c|c|c|c|}
\hline \multirow[t]{2}{*}{ Chemical elements } & \multicolumn{7}{|c|}{ Number of analyzed points according to Fig. 17 [\% mass.] } \\
\hline & $\begin{array}{l}1 \\
\text { Low-Mg calcite }\end{array}$ & $\begin{array}{l}2 \\
\text { High-Mg calcite }\end{array}$ & $\begin{array}{l}3 \\
\text { Low-Mg calcite }\end{array}$ & $\begin{array}{l}4 \\
\text { Protodolomite }\end{array}$ & $\begin{array}{l}5 \\
\text { High-Mg calcite }\end{array}$ & $\begin{array}{l}6 \\
\text { Low-Mg calcite }\end{array}$ & $\begin{array}{l}7 \\
\text { Low-Mg calcite }\end{array}$ \\
\hline $\mathrm{C}$ & 10.40 & 7.90 & 12.40 & 12.70 & 12.00 & 12.70 & 12.00 \\
\hline $\mathrm{Mg}$ & 2.70 & 9.80 & 4.40 & 11.00 & 7.30 & 3.20 & 4.10 \\
\hline $\mathrm{Ca}$ & 36.80 & 29.10 & 36.50 & 19.20 & 29.40 & 32.60 & 34.00 \\
\hline $\mathrm{Fe}$ & 0.00 & 6.80 & 0.00 & 1.00 & 0.00 & 0.00 & 0.00 \\
\hline $\mathrm{O}$ & 50.10 & 46.40 & 46.70 & 56.10 & 51.30 & 51.50 & 49.90 \\
\hline Total & 100.00 & 100.00 & 100.00 & 100.00 & 100.00 & 100.00 & 100.00 \\
\hline $\mathrm{MgCO}_{3}$ content & 9.45 & 34.30 & 15.40 & 38.50 & 25.55 & 11.20 & 14.35 \\
\hline
\end{tabular}

Table 10 Results of ICP AES analysis

\begin{tabular}{lllll}
\hline Chemical elements & \multicolumn{2}{l}{ Number of analyzed samples } & \\
\cline { 2 - 5 } & $\begin{array}{l}\text { Sample 7 } \\
\text { Lower Crinoidea } \\
\text { limestone }\end{array}$ & $\begin{array}{l}\text { Sample 1 } \\
\text { Lower Biohermal } \\
\text { limestone }\end{array}$ & $\begin{array}{l}\text { Sample 22 } \\
\text { Upper Crinoidea } \\
\text { limestone }\end{array}$ & $\begin{array}{l}\text { Sample 41 } \\
\text { Upper } \\
\text { Biohermal } \\
\text { limestone }\end{array}$ \\
\hline $\mathrm{Ca}(\%)$ & 31.50 & 29.40 & 27.30 & 32.90 \\
$\mathrm{Mg}(\%)$ & 7.00 & 7.70 & 9.00 & 9.10 \\
$\mathrm{Fe}(\%)$ & 0.25 & 0.20 & 0.19 & 0.22 \\
$\mathrm{Mn}(\mathrm{ppm})$ & 450 & 430 & 520 & 550 \\
$\mathrm{Sr}(\mathrm{ppm})$ & 135 & 120 & 175 & 190 \\
$\mathrm{Ba}(\mathrm{ppm})$ & 120 & 105 & 155 & 170 \\
\hline
\end{tabular}

in the carbonate phases indicates that the primary sediment consist of aragonite as well. This mineral was transformed into low-Mg calcite during a process of dissolution, when the micritic and palisade cements were formed (the eogenetic stage of diagenesis).

\section{Preservation conditions of the high-Mg calcite in the Muschelkalk sediments}

\section{High-Mg calcite in lower Muschelkalk of Opole Silesia}

The results of the analyses allowed to show that in all formations of Muschelkalk high magnesium calcite is present apart from low-Mg calcite, dolomite, and smaller amounts of quartz and clay minerals.

The results of a microscopic analysis, microprobe measurements executed using the WDS method and a mapping carried out by microprobe measurements applying the EDS method allowed to show that small xenomorphic crystals of high-Mg calcite build the rock mass of bioclastic and organodetritic limestones together with low magnesium calcite. This rock mass could be micritic, microsparry or sparry. High-Mg calcite also forms small xenomorphic crystals in the micritic rock mass of dolomite limestone. Therefore, it was not possible to distinguish this carbonate phase from
low-Mg calcite in the thin sections and in most of the BSE images. Only the microprobe measurements executed in some points confirmed the presence of high-Mg calcite in the investigated limestones. This unstable carbonate phase was also identified on the basis of the results of Fourier Transform Infrared Spectroscopy, X-ray diffraction and ICP OES Spectroscopy.

In infra-red absorption curves high magnesium calcite was identified on the basis of the $V_{3}$ absorption band (values from 1428 to 1435 ), $V_{1}+V_{3}$ absorption band (values from 2517 to 2521) and in some samples on the basis of other absorption bands like 2621, 2625, 2939, 2942, 3021 and 3470 . The absorption bands of this carbonate phase have higher values than those typical for low magnesium calcite but lower than the ones prevalent for dolomite (Ahn et al. 1996; Böttcher et al. 1997; Ji et al. 2009; Pokrovsky et al. 2000). The results of a FTIR analysis allowed to indicate increased content of $\mathrm{Mg}$ in high magnesium calcite of upper Biohermal limestone in comparison with the carbonate phase of other limestone formations. The results of the FTIR analysis were confirmed by results of X-ray diffraction. High-Mg calcite diffraction lines observed in X-ray diffraction patterns show constants of the lattice lower in comparison to the typical ones for low magnesium calcite. For this reason high magnesium calcite was identified mainly on the 
basis of the following $d_{\mathrm{hkl}}$ values: $2.990 \AA$ ( $\left.I=100\right), 2.266 \AA$ $(I=15), 1.857 \AA$ ( $(I=15), 1.423 \AA(I=3), 1.410 \AA(I=3)$, $1.193 \AA(I=3)$.

More details, connected especially with the chemical formula and the crystal structure of high-Mg calcite were obtained during microprobe measurements carried out using the WDS method and a mapping made with application of the EDS method. The results of the measurements allowed to show that high magnesium calcite of each limestone formation are characterized by different content of $\mathrm{Mg}$. The lowest amount of magnesium in high-Mg calcite was observed in limestones of lower Crinoidea formation, which built the lower part of the lower Muschelkalk Profile. The highest amount is present in the limestones of Lower Biohermal Formation. The content of $\mathrm{MgCO}_{3}$ in high magnesium calcite of investigated rocks ranges in lower Crinoidea limestonefrom 22.82 to $33.11 \%$, in lower Biohermal limestone-from 29.61 to $36.89 \%$, in upper Crinoidea limestone the value is $30.52 \%$ and in upper Biohermal limestone it ranges from 30.76 to $34.02 \%$. According to the results of the microprobe measurements, the highest content of $\mathrm{MgCO}_{3}$ in low magnesium calcite has a value of $8.22 \%$ and the lowest amount of $\mathrm{MgCO}_{3}$ in protodolomite is $40.60 \%$. Therefore, the amounts of $\mathrm{MgCO}_{3}$ in high- $\mathrm{Mg}$ calcites of the investigated limestones are higher than in low magnesium calcite but lower than in dolomite.

The median values of magnesium calculated for high-Mg calcite of the investigated limestones show that high magnesium calcite of Biohermal limestones generally contains higher amount of magnesium (median value-above $9 \%$ of $\mathrm{Mg}$ ) than Crinoidea limestones (median value-below 9\% of $\mathrm{Mg}$ ). The content of $\mathrm{MgCO}_{3}$ calculated for the lowest amount of $\mathrm{Mg}$ : $6.52 \%$ of high-Mg calcite exceeds the value of $22.82 \%$. In the case of the highest amount of Mg: 10.54\% the calculated value of $\mathrm{MgCO}_{3}$ is $36.90 \%$. The results of the microprobe measurements allowed to determine a high magnesium calcite chemical formula, which presents the possible range of magnesium content in crystal of high- $\mathrm{Mg}$ calcite. According to the results of microprobe measurements general chemical formulas of high magnesium calcite are as following: $\left(\mathrm{Ca}_{0.87-0.80}, \mathrm{Mg}_{0.13-0.20}\right) \mathrm{CO}_{3}$ for lower Crinoidea limestone, $\left(\mathrm{Ca}_{0.83-0.75}, \mathrm{Mg}_{0.17-0.25}\right) \mathrm{CO}_{3}$ for lower Biohermal limestone, $\left(\mathrm{Ca}_{0.81}, \mathrm{Mg}_{0.19}\right) \mathrm{CO}_{3}$ for upper Crinoidea limestone and $\left(\mathrm{Ca}_{0.78-0.77}, \mathrm{Mg}_{0.22-0.23}\right) \mathrm{CO}_{3}$ for upper Biohermal limestone. The chemical formulas show that high magnesium calcites of Biohermal limestones generally contain higher amounts of magnesium than high-Mg calcites of Crinoidea limestones. The content of $\mathrm{MgCO}_{3}$ of high- $\mathrm{Mg}$ calcite exceeds the value of $22.7 \%$. The results of the microprobe measurements executed using the WDS method were confirmed by the data obtained by mapping. The results of the mapping also allowed to indicate that micritic grains of high-Mg calcite are mixed with micritic grains of low-Mg calcite. These two carbonate phases build the limestone rock mass. Moreover, the results confirmed the occurrence of protodolomite in the investigated rocks and, subsequently the theory of a primary origin of high-Mg calcite and protodolomite. The results of mapping executed by microprobe measurements with application of EDS method allowed to show that high magnesium calcite forms micritic grains which are mixed with micritic grains of low-Mg calcite. Thus, it was not possible to analyze the changes of magnesium content inside a single crystal of this carbonate phase. The changes of $\mathrm{Mg}$ amount could be observed only in crystals of dolomite phase. The amount of $\mathrm{Ca}$ in high- $\mathrm{Mg}$ calcite phase ranges from 18.20 to $33.60 \%, \mathrm{Mg}$ : from 7.30 to $10.20 \%$, C: from 7.90 to $15.00 \%$ and O: from 46.40 to $55.40 \%$. But low content of magnesium in dolomite phase in comparison with stoichiometric value for dolomite: $13.18 \%$ (46.13\% of $\mathrm{MgCO}_{3}$ ) and the lack of big changes of $\mathrm{Mg}$ inside of single dolomite crystals seem to be of more importance here. These indicate the presence of protodolomite in the investigated limestones. This non-stoichiometric, poorly ordered carbonate phase which forms euhedral and rhombohedral-shaped crystals is usually created in shallow epicontinental seas during early stages of diagenesis (Boggs 2010; Morse and Mackenzie 1990; Tucker and Wright 1990).

The results of all executed analyses allowed to indicate the presence of high-Mg calcite in the investigated limestones. It was important to compare the results of all analyses, especially results of the X-ray diffraction and the microprobe measurements. According to Zhang et al. (2010), with the increase of $\mathrm{MgCO}_{3}$ content in high magnesium calcite, the values of cell parameters- $a_{0}(\AA)$ and $c_{0}(\AA)$ drop. Analyzing data obtained by Zhang et al. (2010), it is possible to determine cell parameters on the basis of $\mathrm{MgCO}_{3}$ content. When the amount of $\mathrm{MgCO}_{3}$ is $22.7 \%$, the cell parameters of high- $\mathrm{Mg}$ calcite present general values as follows: $a_{0}=4.91 \AA, c_{0}=16.65 \AA$ and for the amount of $\mathrm{MgCO}_{3}$ $36.71 \%$ the cell parameters present general values: $a_{0}=4.88$ $\AA, c_{0}=16.45 \AA$ (Zhang et al. 2010). On the basis of the peak values, mainly of $d_{104}$, visible in the X-ray diffraction patterns of investigated limestones, $a_{0}$ and $c_{0}$, the parameters established according to the ICDD Card Index have the following values: $a_{0}=4941 \AA$, $c_{0}=16,854 \AA$. These values, similar to the parameters established by Johnson (2002) $\left(a_{0}=4.942 \AA\right.$ and $c_{0}=16.85 \AA$ ) for $47.6 \%$ of $\mathrm{MgCO}_{3}$, indicate the presence of an increased amount of magnesium in high-Mg calcite. However, these values were not calculated but established only on the basis of the data from the ICDD Card Index. The results of the microprobe measurements show that the amount of $\mathrm{MgCO}_{3}$ in high magnesium calcite varies from 22.82 to $36.89 \%$. It indicates the different content of magnesium in high- $\mathrm{Mg}$ calcite. This analysis was executed in individual points, so the differences could be observed not only in calcium and magnesium contents but 
also in iron content. Generally speaking higher amounts of iron were observed in the carbonate phases showing also increased amounts of magnesium. It is probably connected with the possibility of magnesium being substituted by iron in the carbonate phases rich in magnesium. Some factors influence the substitution. The most important are: cationic size, cationic radius, $\mathrm{M}-\mathrm{O}$ bond length, cell volumes, correlation between $\mathrm{M}-\mathrm{O}$ bond length and $c / a$ ratios (Tucker and Wright 1990). Fe could substitute Mg because these two chemical elements have similar cationic size and length of the cationic radius.

As a result of magnesium substitutions in the crystals of high-Mg calcite, the structure of crystal cells is different in comparison with a low magnesium calcite crystal. It is connected with a difference in the size of the ionic radius of $\mathrm{Ca}$ and the ionic radius of $\mathrm{Mg}$ (Titiloye et al. 1998; Tsipursky and Buseck 1993). Ca and Mg ions take the positions in space network alternately along the threefold axis; therefore the symmetry of calcite is reduced. Instead of a scalenohedral ditrigonal symmetry, which includes $3 \mathrm{~L}^{2}$ (three twofold axes) apart from other symmetry parameters, a rhombohedral symmetry similar to the symmetry of a dolomite crystal structure occurs. It can be observed in carbonate minerals rich in magnesium, such as: protodolomite $\left(\mathrm{Ca}_{0.5}, \mathrm{Mg}_{0.5} \mathrm{CO}_{3}\right.$; space group $\mathrm{R} 3 \mathrm{c})$, ordered dolomite $\left(\mathrm{Ca}_{0.5}, \mathrm{Mg}_{0.5} \mathrm{CO}_{3}\right.$; space group R3), huntite $\left(\mathrm{Ca}_{0.25}, \mathrm{Mg}_{0.75} \mathrm{CO}_{3}\right.$; space group R32) and magnesite $\left(\mathrm{MgCO}_{3}\right.$; space group $\left.\mathrm{R} 3 \mathrm{c}\right)$ (Böttcher et al. 1997). The symmetry of a high magnesium calcite crystal is rhombohedral with the space group R3c (Althoff 1977; Paquette and Reeder 1990), similar to the one typical for protodolomite.

\section{The theory on the preservation conditions of high-Mg calcite}

The results of the study allowed to show that the highest content of $\mathrm{Mg}$ in high magnesium calcite characterizes rocks of lower Crinoidea Beds and the lowest-rocks of upper Biohermal Beds, so the content of Mg decrease from the bottom to the top of analyzed profile. This falling trend of $\mathrm{Mg}$ towards the top of the section is indicative of diagnenetic processes influence. Meteoric water induced depletion of $\mathrm{Mg}$. Karchowice Beds represent barrier sediments of reef facies (Bodzioch 2005). Their formation was connected with the beginning of the sea regression. The sea-level fall could cause a progressive increase of salinity. Normally, the high-Mg calcite is transformed into low-Mg calcite with increasing burial depth and low magnesium calcites dominate in the ancient limestones. Aragonite and high-Mg calcite are the dominant carbonate phases in warm tropical to subtropical waters. In cooler waters and in the depth of the ocean, the $\mathrm{Mg}$ content decrease and low magnesium calcite dominates (Mackenzie and Andersson 2013). The temperature and the $\mathrm{Mg} / \mathrm{Ca}$ ratio are factors increased the probability of dolomite and calcites rich in $\mathrm{Mg}$ formation and high-Mg calcite preservation (Morse and Mackenzie 1990). When the temperature of seawater is typical for tropical seas $\left(25-30{ }^{\circ} \mathrm{C}\right)$ but the $\mathrm{Mg} / \mathrm{Ca}$ ratio is below 1 , low magnesium calcite precipitates. When $\mathrm{Mg} / \mathrm{Ca}$ ratio is above 1 at normal temperatures, high magnesium calcite precipitates. These conditions could also cause a poorly ordered protodolomite formation (Boggs 2010). The content of $\mathrm{Mg}$ increases with the increase of $\mathrm{Mg} / \mathrm{Ca}$ ratio depending on temperature (Stanley et al. 2002; Stanley 2008). At temperatures over $42{ }^{\circ} \mathrm{C}$, high-Mg calcite with the content of up to $15 \mathrm{~mol} \%$ of $\mathrm{MgCO}_{3}$ is stable in relation to low-Mg calcite (Bertram et al. 1991). The calculated temperatures of low-Mg calcite crystallization (Stanienda 2011, 2013) exceeds the value of $42{ }^{\circ} \mathrm{C}$. For lower Crinoidea limestone it is $59.66^{\circ} \mathrm{C}$, for upper Crinoidea limestone-from 61.10 to $65.97{ }^{\circ} \mathrm{C}$ and for Upper Biohermal Limestone-from 58.82 to $76.29^{\circ} \mathrm{C}$. Crystallization temperatures of high-Mg calcite present values: for upper Crinoidea limestone-from 49.94 to $53.71^{\circ} \mathrm{C}$ and for Upper Biohermal Limestone- $64.91{ }^{\circ} \mathrm{C}$ (Stanienda 2013). They are not normal temperatures even for tropical seawaters. Therefore, the results can suggest the influence of diagenetic processes on high- $\mathrm{Mg}$ calcite preservation, because this carbonate phase could be preserved in higher temperatures. Diagenesis started after the deposition of sediment. However, some diagenetic processes started before sediment compaction. The temperature increase is connected with burial depth. Preservation of high-Mg calcite depends also on different other factors such as $\mathrm{Mg} / \mathrm{Ca}$ ratio, solubility, calcium and magnesium ion activity, the type of environment, as well as on the influence of marine organisms. Based on $\mathrm{Mg}$ content of well preserved Triassic echinoderms, Dickson (2004), estimated that the Triassic seawater $\mathrm{Mg} / \mathrm{Ca}$ ratio had a value of about 3.4. Nevertheless, it has been recently argued that application of fossil echinoderms to seawater $\mathrm{Mg} / \mathrm{Ca}$ reconstructions is unreliable (Gorzelak et al. 2013, 2016). As inferred from the Hardie (1996) curve, $\mathrm{Mg} / \mathrm{Ca}$ ratio of Triassic seawater was slightly lower; it ranged from about 2.5-3. Therefore, also the conditions of seawater (probably tropical shallow sea), especially higher salinity along with value of $\mathrm{Mg} / \mathrm{Ca}$ ratio of seawater connected with the shallowing of the sea basin, increased content of $\mathrm{Na}$ (Stanienda 2000, 2011, 2013), $\mathrm{CO}_{2}$, pressure and also neomorphic processes (Boggs 2010) could influence the preservation of high magnesium calcite in Muschelkalk limestones of the Polish part of the Germanic Basin. The general effect of diagenesis, especially in vadose zone, is a destruction of less-stable aragonite and low magnesium calcite and concomitantly generating stable high-Mg calcite (Boggs 2010). Therefore, the most probable is the influence of diagenetic processes - a marine water drainage, increase of temperature and of other seawater-factors (increased 
$\mathrm{CO}_{2}$, increased salinity, pressure) also neomorphism which could finally caused the preservation of high-Mg calcite.

\section{Condition and environment of high-Mg calcite formation}

Analyzing the possibilities of high-Mg calcite forming, the carbonate phase is characterized by a higher than in low magnesium calcite but lower than in the protodolomite amount of magnesium. This mineral was created in a shallow sea, in an environment of warm, salty seawater, inside a carbonate sediment during its compaction (early stage of diagenesis). The analyzed rocks, which contain high-Mg calcite, were formed in the eastern part of the Germanic Basin, in a shallow zone during the beginning of the sea regression. The salinity of the water was probably increasing because of the shallowing of the sea basin. The variety of chemical elements indicates the increased salinity of seawater in which high magnesium calcite was formed. While analyzing the possibility of the influence of dolomitization on the high-Mg calcite formation it is necessary to say that dolomitization of aragonite proceeds faster than dolomitization of calcite (Morse and Mackenzie 1990). High magnesium calcite may or may not be dolomitized faster than low magnesium calcite (Morse and Mackenzie 1990). It depends of different factors: solubility, $\mathrm{Mg} / \mathrm{Ca}$ ratio, temperature, $\mathrm{Ca}$ and $\mathrm{Mg}$ ion activity. In case of the investigated Crinoid limestones, some amounts of magnesium could come from marine organisms: shells and different parts of skeletons, which had an elevated level of high-Mg calcite. It was possible to observe crinoid circular stem plates both with the naked eye and during the microscopic analysis. Some of them are built of micritic calcite, others of single calcite crystals, with a rhombohedral cleavage visible in some examples. Micritic calcite, which forms stem plates, could be the primary calcite phase. However, while studying thin sections, it was impossible to distinguish between low-Mg calcite and high-Mg-calcite. The single calcite crystals with a visible cleavage, which built stem plates, are probably the second generation calcite crystals which could be formed by a transformation of the primary carbonate phases during the diagenetic processes. After the carbonate material deposition during the shallowing of the sea basin, the compaction processes began (early stage of diagenesis-eogenetic stage). It was characterized by a reduction of water in sediment and a concentration of chemical components. It also caused an increase of salinity of the carbonate material what could also influence the preservation of high magnesium calcite. Effects of different types of diagenesis were observed in the studied limestones. Destructive diagenesis is mainly connected with the activity of marine organisms, which changed the surface of bioclasts by burrowing. Burrows were filled with microcrystalline calcium carbonate-aragonite or high-Mg calcite. The presence of $\mathrm{Sr}$ and $\mathrm{Ba}$ in the carbonate phases indicates that the primary sediment also included aragonite which was transformed into low-Mg calcite during the process of dissolution, when the micritic and palisade cements were formed (the eogenetic stage of diagenesis). During the eogenetic stage of diagenesis high- $\mathrm{Mg}$ calcite and dolomite were created. According to Boggs (2010), Fairbridge (1957), Flügel (2004) and Szulc (1990, 2000), skeletons of marine fauna are other source of magnesium (skeletons of echinoderms, coralline algae, foraminifers). Echinoderms, especially crinoids dominate in analyzed rocks. During the mesogenetic stage of diagenesis, the mineral phases of carbonate sediment underwent aggradation, recrystallization, dissolution and transformation processes. Dissolution processes were taking place under pressure in reductive environment. Iron, which replaced magnesium in carbonate crystals, was released from these crystals and filled stylolites, which were formed during the dissolution of carbonates. Analyzing the tests results and the type of the environment in which diagenetic processes, which allowed for high-Mg calcite formation, take place (Tucker and Wright 1990) and using the Boggs (2010) division, it can be assumed that the diagenetic processes in limestones of the Polish part of the Germanic Basin could probably occur in the following zones: in the deep sea zone-phreatic sea zone and in the zone of the shallow sea floor and shallow subsurface areas). In some areasin meteoric zone.

\section{Conclusions}

The principal results can be summarized as follows:

1. The results of the executed analyses allowed to confirm the hypothesis of the high magnesium calcite presence in Karchowice Beds of the area of Polish part of the Germanic Basin.

2. Micritic grains of high-Mg calcite are mixed with micritic grains of low magnesium calcite. These two carbonate phases built the rock mass in bioclastic and organodetritic limestones.

3. The results of the microprobe measurements allowed to show that, the amount of $\mathrm{MgCO}_{3}$ in high magnesium calcite ranges from 22.82 to $36.89 \%$ and it ranges in lower Crinoidea limestone-from 22.82 to $33.11 \%$, in lower Biohermal limestone-from 29.61 to $36.89 \%$, in upper Crinoidea limestone the value is $30.52 \%$ and in upper Biohermal limestone it ranges from 30.76 to $34.02 \%$. These values are higher than the highest calculated value for low-Mg calcite- $8.22 \%$ of $\mathrm{MgCO}_{3}$ and the lowest value calculated for protodolomite- $40.60 \%$ of $\mathrm{MgCO}_{3}$.

4. The results of the microprobe measurements, allowed to determine the high magnesium calcite general chemi- 
cal formula, which presents a possible range of the magnesium content in the crystals of high-Mg calcite. High-Mg calcite of lower Crinoidea limestone has a chemical formula as follows: $\left(\mathrm{Ca}_{0.87-0.80}, \mathrm{Mg}_{0.13-0.20}\right)$ $\mathrm{CO}_{3}$. A general chemical formula of high magnesium calcite of lower Biohermal limestone is as follows: $\left(\mathrm{Ca}_{0.83-0.75}, \mathrm{Mg}_{0.17-0.25}\right) \mathrm{CO}_{3}$, of upper Crinoidea limestone is $\left(\mathrm{Ca}_{0.81}, \mathrm{Mg}_{0.19}\right) \mathrm{CO}_{3}$ and the formula of upper Biohermal limestone is $\left(\mathrm{Ca}_{0.78-0.77}, \mathrm{Mg}_{0.22-0.23}\right) \mathrm{CO}_{3}$.

5. On the basis of the peak values, mainly of $d_{104}$, visible in the X-ray diffraction patterns of samples, according to the ICDD Card Index, $a_{0}$ and $c_{0}$ parameters were established. The values are: $a_{0}=4941 \AA, c_{0}=16,854$ $\AA$. These data confirm the presence of high-Mg calcite. The form of high-Mg calcite-micritic grains and the occurrence of protodolomite in the investigated limestones which present a similar content of $\mathrm{Mg}$ in different points inside of a single crystal, confirm the theory of the secondary, early diagenetic origin of this unstable carbonate phase and the same origin of protodolomite. High-Mg calcite was formed in the epicontinental Germanic Basin, in the environment of warm, salty sea water, inside a carbonate sediment during its compaction (early stage of diagenesis-eogenetic), at the same time as protodolomite. However, some amount of $\mathrm{Mg}$ calcite, which was part of marine organism could build together with aragonite the primary sediment. The conditions of seawater, especially higher salinity and also advanced diagenetic processes including neomorphism influenced the preservation of high magnesium calcite, unstable carbonate phase, in Muschelkalk limestones of the Polish part of the Germanic Basin.

Open Access This article is distributed under the terms of the Creative Commons Attribution 4.0 International License (http://creativeco mmons.org/licenses/by/4.0/), which permits unrestricted use, distribution, and reproduction in any medium, provided you give appropriate credit to the original author(s) and the source, provide a link to the Creative Commons license, and indicate if changes were made.

\section{References}

Ahn DJ, Berman A, Charych D (1996) Probing the dynamics of template-directed calcite crystallization with in situ FTIR. J Phys Chem 100:12455-12461

Althoff PL (1977) Structural refinements of dolomite and a magnesian calcite and implications for dolomite formation in the marine environment. Am Mineral 62:772-783

Bertram MA, Mackenzie FT, Bishop FC, Bischoff WD (1991) Influence of temperature on the stability of magnesian calcite. Am Mineral 76:1889-1896

Bodzioch A (2005) Biogeochemical diagenesis of the Lower Muschelkalk of Opole region. Adam Mickiewicz University Press, Poznań
Boggs S Jr (2010) Petrology of sedimentary rocks, 2nd edn. Cambridge University Press, Cambridge

Böttcher ME, Gehlken PL, Steele DF (1997) Characterization of inorganic and biogenic magnesian calcites by Fourier transform infrared spectroscopy. Solid State Ionics 101-103:1379-1385

Deleuze M, Brantley SL (1997) Inhibition of calcite crystal growth by $\mathrm{Mg}^{2+}$ at $100^{\circ} \mathrm{C}$ and 100 bars: influence of growth regime. Geochimica et Cosmochimica Acta 61(7):1475-1485

Dickson J (2004) Echinoderm skeletal preservation: calcite-aragonite seas and the $\mathrm{Mg} / \mathrm{Ca}$ ratio of Phanerozoic oceans. J Sediment Res 74(3):355-365. https://doi.org/10.1306/112203740355

Dunham RJ (1962) Classification of carbonate rocks according to depositional texture. In: Ham WE (ed) Classification of carbonate rocks. A symposium. Am. Assoc. Petrol. Geol. Mem., vol 1, pp 108-171

Embry AF, Klovan JE (1971) A late Devonian reef tract on northeastern Banks Island. N.W.T. Bull Can Petrol Geol 19:730-781

Fairbridge RW (1957) The dolomite question. Soc Econ Paleontol Mineral Spec Pub 5:164-170

Fairchild IJ, Borsato A, Tooth AF, Frisia S, Hawkesworth CJ, Huang Y, Mc Dermott F, Spiro B (2000) Controls on trace element (Sr-Mg) composition of carbonate cave waters: implication for speleothem climatic records. Chem Geol 166:255-269

Feist-Burkhardt S, Götz AE, Szulc J, Borkhataria R, Geluk M, Haas J, Hornung J, Jordan P, Kempf O, Michalik J, Nawrocki J, Reinhardt L, Rickem W, Röhling HG, Rüffer T, Török Á, Zühlke R (2008) Triassic. In: McCann T (ed) The geology of Central Europe. Volume 2: Mesozoic and cenozoic. The Geological Society, London

Flügel E (2004) Microfacies in carbonate rocks. Analysis, interpretation and application. Springer-Verlag, Berlin

Gorzelak P, Stolarski J, Mazur M, Meibom A (2013) Micro- to nanostructure and geochemistry of extant crinoidal echinoderm skeletons. Geobiology 11(1):29-43. https://doi.org/10.1111/gbi.12012

Gorzelak P, Krzykawski T, Stolarski J (2016) Diagenesis of echinoderm skeletons: constraints on paleoseawater $\mathrm{Mg} / \mathrm{Ca}$ reconstructions. Glob Planet Change 144:142-157

Hardie LA (1996) Secular variation in seawater chemistry: an explanation for the coupled secular variation in the mineralogies of marine limestones and potash evaporates over the past 600 m.y. Geology 24(3):279-283

Ji J, Ge Y, Balsam W, Damuth JE, Chen J (2009) Rapid identification of dolomite using a Fourier transform infrared spectrophotometer (FTIR): a fast method for identifying Heinrich events in IODP Site U1308. Mar Geol 258:60-68

Johnson N (2002) Kratos analytical, a Shimadzu Group Company. http://www.kratos.com/XRD/Apps/geol.html. Accessed 11 Dec 2002

Mackenzie FT, Andersson AJ (2013) The marine carbon system and ocean acidification during Phanerozoic time. Geochem Perspect $2: 1$

Markgraf SA, Reeder RJ (1985) High-temperatures structure refinements of calcite and magnesite. Am Mineral 70:590-600

Morse JW, Mackenzie FT (1990) Geochemistry of sedimentary carbonates, vol 33. Elsevier, Amsterdam, p 707

Morse JW, Andersson AJ, Mackenzie FT (2006) Initial responses of carbonate-rich shelf sediments to rising atmospheric $\mathrm{pCO}_{2}$ and "ocean acidification": role of high $\mathrm{Mg}$-calcites. Geochim Cosmochim Acta 70:5814-5830

Niedźwiedzki R (2000) Lithostratygraphy of Górażdże Formation and Dziewkowice Formation in the Opole Silesia (Litostratygrafia formacji górażdżańskiej i formacji dziewkowickiej na Śląsku Opolskim). Geological and Mineralogical Works of Wrocław University LXXI, Wrocław

Paquette J, Reeder RJ (1990) Single-crystal X-ray structure refinements of two biogenic magnesian calcite crystals. Am Mineral $75: 1151-1158$ 
Pokrovsky OS, Mielczarski JA, Barrea O, Schott J (2000) Surface speciation models of calcite and dolomite aqueous solution interfaces and their spectroscopic evaluation. Langmuir 16:2677-2688

Smyth JR, Ahrens TJ (1997) The crystal structure of calcite III. Geophys Res Lett 24(13):1595-1598

Stanienda K (2000) Influence of dolomitization processes on the Triassic limestones from Tarnów Opolski Deposit and the possibility of limestone application in desulphurization of flue gases. Dr. Sci. Thesis, Silesian Univ. of Technology (Gliwice in Poland)

Stanienda K (2004) Investigations of diagenetic processes in the dolomitic limestones from the „Tarnów Opolski” Deposit. Sci J Silesian Univ Technol (Zeszyty NaukowePolitechniki Śląskiej), series: Mining (Górnictwo) 260:205-216

Stanienda K (2005) Identification of the carbonate phases in the Karchowice and Diplopora Beds (Muschelkalk sediments) from the Lower Silesia. Scientific Journals of Silesian University of Technology (Zeszyty Naukowe Politechniki Śląskiej), series: Mining (Górnictwo) 269:149-157

Stanienda K (2006) Carbonates in the Triassic rocks from the area of Tarnów Opolski. Min Resour Manag 22(3):243-251

Stanienda K (2011) Effects of dolomitization processes in the Triassic limestone of Tarnów Opolski Deposit. The Silesian University of Technology Press, Gliwice

Stanienda K (2013) Diagenesis of the Triassic limestone from the Opole Silesia in the aspect of magnesian calcite presence. The Silesian University of Technology Press, Gliwice

Stanley SM (2008) Effects of global seawater chemistry on biomineralization: past, present, and future. Department of Geology \& Geophysics, University of Hawaii, Honolulu
Stanley SM, Ries JB, Hardie LA (2002) Low-magnesium calcite produced by coralline algae in seawater of Late Cretaceous composition. PNAS 99(24):15323-15326

Szulc J (1990) The Muschelkalk-sedimentary environments, facies and diagenesis. Excursion guidebook and abstracts. In: International workshop-field seminar. pp 1-32

Szulc J (1993) Early alpinie tectonics and lithofacies succesion in the Silesian part of the Muschelkalk Basin. A synopsis. In: Hagdorn H, Seilacher A (eds) Muschelkalk. Goldschneck, Stuttgart, pp $19-28$

Szulc J (2000) Middle Triassic evolution of the northern Peri-Tethys area is influenced by early opening of the Tethys Ocean. Ann Soc Geol Pol 70:1-48

Titiloye JO, De Leeuw NH, Parker SC (1998) Atomistic simulation of the differences between calcite and dolomite surfaces. Geochim Cosmochim Acta 62(15):2637-2641

Tsipursky SJ, Buseck PR (1993) Structure of magnesian calcite from sea urchins. Am Mineral 78:775-781

Tucker ME, Wright VP (1990) Carbonate sedimentology. Blackwell Scientific Publications, Oxford, pp 314-400

Zhang Y, Dave RA (2000) Influence of $\mathrm{Mg}^{2+}$ on the kinetics of calcite precipitation and calcite crystal morphology. Chem Geol 163:129-138

Zhang F, Xu H, Konishi H, Roden EE (2010) A relationship between $\mathrm{d}_{104}$ value and composition in the calcite-disordered dolomite solid-solution series. Am Mineral 95:1650-1656 